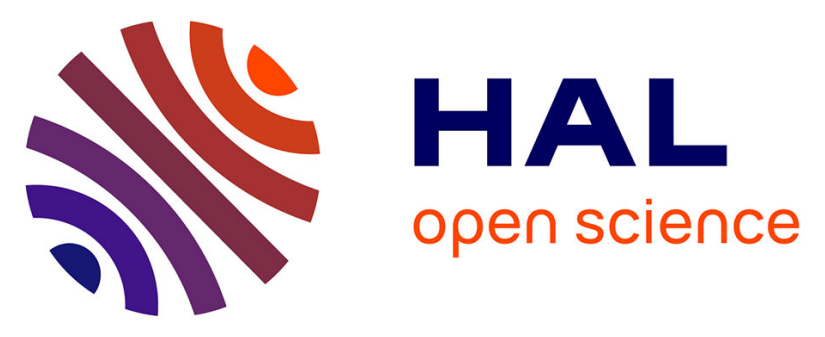

\title{
Unconventional pseudostatic stability analysis of the Diezma landslide (Granada, Spain) based on a high-resolution engineering-geological model
}

José Delgado, J Garrido, Luca Lenti, C Lopez Casado, Salvatore Martino, F. J. Sierra

\section{To cite this version:}

José Delgado, J Garrido, Luca Lenti, C Lopez Casado, Salvatore Martino, et al.. Unconventional pseudostatic stability analysis of the Diezma landslide (Granada, Spain) based on a high-resolution engineering-geological model. Engineering Geology, 2015, 184, pp.81-95.

10.1016/j.enggeo.2014.11.002 . hal-01727003

\section{HAL Id: hal-01727003 \\ https://hal.science/hal-01727003}

Submitted on 8 Mar 2018

HAL is a multi-disciplinary open access archive for the deposit and dissemination of scientific research documents, whether they are published or not. The documents may come from teaching and research institutions in France or abroad, or from public or private research centers.
L'archive ouverte pluridisciplinaire HAL, est destinée au dépôt et à la diffusion de documents scientifiques de niveau recherche, publiés ou non, émanant des établissements d'enseignement et de recherche français ou étrangers, des laboratoires publics ou privés. 


\section{Accepted Manuscript}

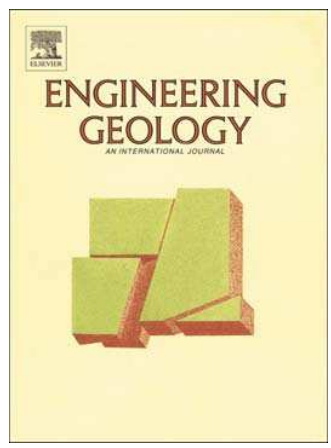

Unconventional pseudostatic stability analysis of the Diezma landslide (Granada, Spain) based on a high-resolution engineering-geological model

J. Delgado, J. Garrido, L. Lenti, C. Lopez-Casado, S. Martino, F.J. Sierra

PII:

S0013-7952(14)00290-7

DOI: doi: $10.1016 /$ j.enggeo.2014.11.002

Reference: $\quad$ ENGEO 3915

To appear in: $\quad$ Engineering Geology

Received date: $\quad 13$ November 2013

Revised date: 20 October 2014

Accepted date: 3 November 2014

Please cite this article as: Delgado, J., Garrido, J., Lenti, L., Lopez-Casado, C., Martino, S., Sierra, F.J., Unconventional pseudostatic stability analysis of the Diezma landslide (Granada, Spain) based on a high-resolution engineering-geological model, Engineering Geology (2014), doi: 10.1016/j.enggeo.2014.11.002

This is a PDF file of an unedited manuscript that has been accepted for publication. As a service to our customers we are providing this early version of the manuscript. The manuscript will undergo copyediting, typesetting, and review of the resulting proof before it is published in its final form. Please note that during the production process errors may be discovered which could affect the content, and all legal disclaimers that apply to the journal pertain. 


\title{
Unconventional pseudostatic stability analysis of the Diezma landslide (Granada, Spain) based on a high-resolution engineering-geological model
}

\author{
Delgado J. ${ }^{\mathrm{a}}$, Garrido J. ${ }^{\mathrm{b}}$, Lenti L. ${ }^{\mathrm{c}}$, Lopez-Casado C. ${ }^{\mathrm{d}}$, Martino S. ${ }^{\mathrm{e}^{*}}$, Sierra F.J.
}

\footnotetext{
${ }^{a}$ Dpt. Ciencias de la Tierra y del Medio Ambiente, Universidad de Alicante, Ap. Correos 99, 03080 Alicante, Spain

${ }^{\mathrm{b}}$ Dpt. Ingeniería Civil, Universidad de Granada, Campus Fuentenueva, Av. Severo Ochoa s/n. 18071 Granada, Spain

${ }^{\mathrm{d}}$ Dpt. Física Teórica y del Cosmos, Universidad de Granada, Campus Fuentenueva, Av. Severo Ochoa s/n, 18071 Granada, Spain

${ }^{c}$ Institut Français des Sciences et Technologies des Transports, de l'Aménagement et des Réseaux (IFSTTAR-Paris) 14-20 Boulevard Newton Cité Descartes Champs sur Marne F-77447 Marne la Vallée Cedex 2, France

${ }^{\text {e }}$ Dpt. Scienze della Terra and Centro di Ricerca per i Rischi Geologici (CERI), Università di Roma, "Sapienza", P.le Aldo Moro 5, 00185 Roma, Italy

${ }^{\mathrm{f}}$ Servicio de Carreteras. Consejería de Fomento y Vivienda. Junta de Andalucía. C/ Joaquina Eguaras 2. 18071 Granada.

* Corresponding Author
}

\begin{abstract}
A novel unconventional pseudostatic analysis is proposed here to characterize the sensitivity of a landslide involved slope to earthquakes characterized by different physical properties. Several sine waves with different amplitudes, frequencies and phases were applied to the landslide mass assuming limit equilibrium conditions. The unconventional approach was used for the Diezma landslide case study. The landslide is located $25 \mathrm{~km}$ from the city of Granada (Spain). Although the slope had repeatedly suffered small-scale stability problems since the construction of the A-92 highway, a larger failure occurred on 18 March 2001 and damaged the highway between kilometers 272.6 and 272.8. The landslide had an estimated volume of 1.2 $\mathrm{Mm}^{3}$ and involved a disordered deposit of silt and clay with heterometric blocks within the Numidoide Formation, which outcrops along the contact between the Maláguide and Dorsal domains of the Betic Cordillera mountain range. Despite the 18 million Euros spent since 1999 on geotechnical investigations and stabilization solutions, the numerous
\end{abstract}


reactivations that occurred through 2010 and 2013 demonstrate the persistent activity of the landslide.

The geometry of the large slope failure corresponding to the first activation of the Diezma landslide was used to back-analyze the stability of the slope based on a high-resolution engineering-geological model. The model was developed from the analysis of numerous borehole $\operatorname{logs}$ as well as from geophysical investigations consisting of seismic noise measurements.

The results demonstrate that the safety factor (SF) of the Diezma landslide varies significantly for frequencies less than $1 \mathrm{~Hz}$; moreover, unstable conditions are reached at frequency values between 0.5 and $1 \mathrm{~Hz}$ for water pressure distributions corresponding to Bishop factors $\left(\mathrm{r}_{\mathrm{u}}\right)$ between 0 and 0.36 . To estimate the co-seismic displacements, the geometrical and mechanical properties of the landslide mass were used to derive its characteristic periods for thickness $\left(\mathrm{T}_{\mathrm{s}}\right)$ and length $\left(\mathrm{T}_{1}\right)$, which were compared with the characteristic period of the earthquake $\left(\mathrm{T}_{\mathrm{m}}\right)$. The results indicate that the maximum expected co-seismic displacements are up to $2 \mathrm{~m}$ for an earthquake with a $\mathrm{T}_{\mathrm{m}}$ value close to $1 \mathrm{~s}$ and an Arias Intensity on the order of $1 \mathrm{~m} / \mathrm{s}$.

\section{Keywords}

Landslide, engineering-geological model, noise measurements, stability conditions, pseudostatic analysis 


\section{INTRODUCTION}

Several earthquake-induced reactivations of landslides were historically well documented in Italy and Spain; they mainly involved soil slopes and caused the remobilization of already existing sliding masses also in far field locations (Delgado et al., 2011a; Martino et al., 2014). This is the case for the reactivation of the Calitri landslide on 1980 (Martino and Scarascia Mugnozza, 2005) or for the Cerda (Bozzano et al., 2011) and Salcito (Bozzano et al., 2008) landslides on 2002, in Italy, as well as for the reactivation of the Güevéjar (Pintor and Azor, 2006; Rodríguez-Peces et al., 2011b) and of the Albuñuelas landslides (Delgado et al., 2011b), in Spain.

The earthquake-induced landslide reactivation represents a main topic for slope engineering as it needs to be commiserated with stabilization interventions in terms of both project design and technical solutions. The possible interaction of landslide masses with earthquakes has been widely discussed over the last several decades (Martino and Scarascia Mugnozza, 2005; Sepulveda et al., 2005a, b; Danneels et al., 2008; Rodríguez-Peces et al., 2011b; Delgado et al., 2011a; Lenti and Martino, 2012). Such interactions depend on the properties of the landslide mass (i.e., geometrical features and geomechanical properties) as well as on the seismic wave characteristics, including the kinematic physical parameters (i.e., peak ground acceleration - PGA, velocity - PGV and displacement - PGD), the energy of the ground 
motion (commonly expressed by the Arias intensity - AI) and the frequency content, which is represented by the Fast Fourier Transform (FFT) of the seismic input.

Several studies based on field evidence (Del Gaudio and Wasowsky, 2007; Bozzano et al., 2008; Bozzano et al., 2011) or numerical modeling (Bourdeau and Havenith, 2008; Lenti and Martino, 2013) have demonstrated the primary role of the earthquake spectral content in reactivating landslide masses, especially for large landslides (i.e., more than $100 \mathrm{~m}$ long). The earthquake's characteristic frequency of vibration can influence both the local seismic amplification effects and the landslide volume involved in the co-seismic shaking. In this regard, several of these studies criticized the pseudo-dynamic Newmark approaches, which assume a rigid sliding mass and cannot take into account the interaction of seismic waves with the landslide.

In the case of deterministic studies of specific landslides, the lack of information about seismic events (i.e., local earthquake records) makes the application of pseudo-dynamic stability analyses based on Newmark's methods problematic (Newmark, 1965; Rathje and Bray, 2000). However, the conventional and widely used pseudostatic analysis technique (first introduced by Terzaghi, 1950), which is based on the probabilistic PGA values expected at the landslide site (i.e., derived from seismic hazard maps), cannot take into account the role of the input frequency with respect to the local amplification due to the landslide mass or with respect to the co-seismic shaking (Hynes-Griffin and Franklin, 1984; Stewart et al., 2003; Jibson, 2012). These approaches have been widely applied over the last several decades for slope stability analyses of earth dams as well as for proposing pseudostatic coefficients for slope design (Seed and Martin, 1966; Sherard, 1967; Marcuson, 1981; Kramer, 1996). 
An unconventional pseudostatic approach was experienced here to evaluate the stability conditions of the Diezma landslide slope (Granada, Spain) by taking into account the expected PGA from seismic hazard maps as well as the characteristic frequencies of possible earthquakes. To best constrain the physical features of the seismic wave propagation within the landslide mass (i.e., the seismic wave velocity and length as well as the partial landslide mass volumes involved in the co-seismic displacements), a high resolution engineeringgeological model was developed based on the extensive data collected during geomechanical field investigations and laboratory tests that are available in technical reports referred to the Spanish highway A-92 construction began in 1990 (Ofiteco, 2000; Consejería de Obras Públicas y Transportes Junta de Andalucía, 2001; Fundación Agustín de Betancourt 2001a,b). This highway, which extends for approximately $400 \mathrm{~km}$ between the cities of Seville and Almeria, actually represents the most important lifeline in Andalusia (Southern Spain). The construction of the highway was often interrupted by the occurrence of landslides, which affected the natural slopes after cuts were made for roadway trenches (Garrido, 1992). Several stabilization projects were planned and completed, including slope modifications, retaining walls and drainage systems. Nevertheless, because most of these solutions were not properly planned as part of the project but were implemented under emergency conditions, they did not prevent the reactivation of several landslides. Consequently, the A-92 highway became one of the most expensive infrastructure projects in southern Spain. Rodríguez-Peces et al. (2011a) performed an approximate evaluation of the slope stability conditions of the Diezma landslide under seismic conditions. The results indicate that both near and distant seismic events could reactivate the landslide and that the reactivation is controlled by the epicentral distance and the magnitude of the seismic events. 
The Diezma landslide (Fig. 1) involves a slope in an area located $3 \mathrm{~km}$ west of the Diezma village between kilometers 272.6 and 272.8 of the A-92 highway. The slope failure occurred on 18 March 2001 and the central and head zones of the landslide are still active although several stabilization projects (Fig. $2 \mathrm{e}, \mathrm{f}, \mathrm{g}, \mathrm{h}$ ) have been undertaken since the failure, for a total cost of approximately 18 million Euros. These projects include: 34 boreholes drilled during five different campaigns, 89 drainage wells in four drainage barriers, shallow drainages, ditches, the removal of approximately $250.000 \mathrm{~m}^{3}$ of debris and an anchored retaining wall constructed near the foot of the slope that is founded on 37 piles up to $36 \mathrm{~m}$ deep. The last reactivations occurred in 2010 (Rodríguez-Peces et al., 2011a) and 2013 and showed a retrogressive sliding mechanism (Figs. 2d, 3b).

Due to the state of activity of the Diezma landslide, earthquakes may further destabilize the slide and must be taken into account. The landslide is located in a region of moderate seismicity with a maximum peak ground acceleration (PGA) of about $0.10 \mathrm{~g}$ for an expected return period of 475 years (Benito et al., 2010). However, no strong earthquakes (i.e., with a moment magnitude $\left(\mathrm{M}_{\mathrm{w}}\right)$ greater than 5.0) have occurred within $50 \mathrm{~km}$ of the site since the slope failure in 2001.

\section{THE DIEZMA LANDSLIDE}

\subsection{Geological setting}

The Diezma landslide is located along the tectonic contact between the Internal (Maláguide) and Dorsal domains of the Betic Cordillera chain (Sanz de Galdeano et al., 1995). The 
Numidoide Formation outcrops throughout this area and is characterized by an unconformable contact with the deposits of the Maláguide and Dorsal domains (Azañón et al., 2006, 2010; Fig. 4). Mesozoic to Eocene limestones of the Dorsal domain outcrop at the top of the Rias hill; they have been thrust southward over the disordered deposits of the Numidoide Formation (Aquitanian-Burdigalian), which is part of the Campo de Gibraltar Complex and is composed of a silty-clay silo-clastic matrix with heterometric blocks of limestones (Fig. 5a). Several authors (e.g., Azañón et al., 2010) have recognized high plasticity levels in the smectite clay within the Numidoide deposits and associated them with the sliding surface of the Diezma landslide mass. An unconformable contact can be observed in the landslide area between the deposits of the Maláguide domain and the deposits of the Dorsal domain and the Numidoide Formation. The deposits of the Maláguide domain (Paleozoic to Triassic) include the Red Silt (Fig. 5b), Green Clay (Fig. 5c) and Black Schist Formations (Fig.5d). The former represents the local metamorphic bedrock. The Red Silt is composed of silts, clays and sands, while the Green Clay consists of thinly stratified clays that are locally characterized by intense alteration and fragmentation. The Black Schist includes intensely foliated and jointed schists and phyllites.

The complex structural setting of the Diezma landslide was reconstructed by direct field observations and by correlations between borehole stratigraphic logs (Fig. 4). As a result of this reconstruction, one main fault systems can be identified in the landslide slope; a NE-SW trending thrust system, which includes the main fault that thrusts the Dorsal domain over the Maláguide domain as well as secondary thrusts that thrust the Red Silt over the Green Clay and Black Schist (Fig. 4). In addition to this fault system, from borehole data, the contacts 
between materials are slightly displaced in the vertical, even at close distances; this fact has been interpreted as due to a set of fractures with small scale vertical movement that dislodges the lateral continuity of materials. These fractures are deduced from borehole data, but no evidences were found at ground surface; studies are currently in progress to map the nature and extent of these features.

The limestones of the Dorsal domain host a local aquifer that is part of the DespeñaderoCañamaya hydrogeological unit (Azañón et al., 2006) and whose recharge area extends over an area of almost $30 \mathrm{~km}^{2}$. The local aquifer is strongly controlled by the structural setting of the area (García-Dueñas et al., 1980); the "Fuente de la Higuera" spring, which has an average discharge of $1 \mathrm{l} / \mathrm{s}$, is located approximately $1 \mathrm{~km}$ east of the landslide along the main thrust fault between the limestones of the Dorsal domain and the Numidoide Formation. A secondary spring is located at the top of the Rias hill, where the spring water is collected by an old cistern. A drainage system was installed in 2009 to drain water towards a valley to the east of the landslide.

The geological setting of the slope strongly constrains the mechanism of the Diezma landslide: i) the lateral boundaries of the landslide mass are congruent with the NNE-SSW fault system deduced from borehole data; ;i) the landslide mass mainly involves the deposits of the Numidoide Formation, i.e., the thickness of the landslide increases sharply to the south. On the contrary, there is no clear geologic evidence of the landslide's sliding surface while it results clear by analyzing the inclinometer data; the logs available from the boreholes and the drainage wells indicate that the stratigraphic levels and the structural contacts are not continuous across the area. 
Several cross sections were reconstructed longitudinally and transversally to the landslide mass to better define its geological setting. Fig. 6 shows one of the longitudinal cross sections (AA') and two of the transversal cross sections (BB' and $\left.\mathrm{CC}^{\prime}\right)$. The cross sections utilized digital elevation models (DEM) from before construction of the highway and a recent DEM that shows the present day slope except for the upper portion of the hill that was involved in the 2010 and 2013 reactivations of the landslide.

The landslide mass reported in the geological cross sections was reconstructed by considering: i) the stratigraphy from all the available borehole logs (taking into account the topography that existed at the time the boreholes were drilled; this is important because the topography has changed greatly over time); ii) the stratigraphy from the drainage wells; iii) the stratigraphy from the foundation piles of the retaining wall at the foot of the slope; and vi) the inclinometer data and the location of the shear failures observed in some of the drainage wells. In particular, the data from the last 2012 geotechnical campaign, including three boreholes drilled up to $20 \mathrm{~m}$ deep, were considered. Based on the collected data, the maximum depth of the landslide rupture surface is $25 \mathrm{~m}$ below the present ground surface, i.e., after the slope was reshaped in 2001 during stabilization. Moreover, the reconstructed geometry of the landslide mass indicates a primarily translational sliding mechanism (sensu Cruden and Varnes, 1996) that involves the disordered deposits of the Numidoide Formation.

\subsection{Triggering and reactivation of the landslide}


Table 1 summarizes the main events that characterize the activity of the Diezma landslide since 1990, when construction of the A-92 highway began, and the associated stabilization and restoration projects.

Aerial photographs taken prior to highway construction (IECA, 2013) show that the Rias slope lacks vegetation and contains a very low concentration of olive trees, which indicates an unstable area that is most likely affected by soil creep. Based on this evidence, the slope is mapped as landslide debris cover in the official geological map of Spain (García Dueñas et al., 1980), which was edited before the construction of the A-92 highway.

During construction of the A-92 highway $\left(1990\right.$ - 1992), a $30 \mathrm{~m}$ high cut $\left(45^{\circ}\right)$ was excavated for the highway trench. Small landslides have affected the cut since the first stages of construction (Fig. 2a). In September 1991, before the highway opened to traffic, a new landslide occurred at the bottom of the cut and affected the surface of the roadway to Seville. In 1996, a new landslide in the cut was reshaped, and an intermediate berm was constructed. Even though preliminary stabilization measures were adopted (Table 1), the ground cracks gradually involved the slope up to approximately $400 \mathrm{~m}$ from the roadway and reached the old road CN-342 uphill of the slide (Fig. 1, 4). Most of the cracks coinciding with the boundaries of the 2001 failure were detected and mapped in 1998 (Ofiteco, 2000). In May 2000, a new landslide occurred in the highway trench and again interrupted the highway to Seville. Finally, on 18 March 2001, a more generalized failure occurred; this failure can be considered as the first activation of the Diezma landslide. This event heavily damaged the highway (Fig. 2b) and the old road to Granada (CN-342). The detachment area of the landslide is located at approximately $1280 \mathrm{~m}$ a.s.l. near the old national road CN-342 (Fig. 2c) 
and is identified by a main scarp approximately $4 \mathrm{~m}$ high, secondary scarps approximately $4-5$ $\mathrm{m}$ high and several ground cracks with apertures of approximately $70 \mathrm{~cm}$ across the landslide mass. The Diezma landslide is an earthslide that is characterized by a mainly translational mechanism. It is approximately $400 \mathrm{~m}$ long and $200 \mathrm{~m}$ wide, which corresponds to approximately 6 ha of the slope surface, and it involves a volume of approximately $1.2 \mathrm{Mm}^{3}$ (Fig. 4). In 2002, after the stabilization project was completed, a topographic monitoring system was installed that includes 29 benchmarks and 10 inclinometers within the landslide mass.

As has been reported by other authors (Yesares et al., 2004; Azañon et al. 2010; RodríguezPeces et al., 2011a), the 2001 landslide occurred 20 days after a period of intense rainfall (from December 2000 to February 2001). This period was characterized by daily rainfall of up to $40 \mathrm{~mm}$ (Rodríguez -Peces et al., 2011a) measured at the Quentar pluviometric station (30 $\mathrm{km}$ southwest of Diezma). The average annual rainfall at this station since 1898 is approximately $325 \mathrm{~mm}$; the minimum rainfall of $128 \mathrm{~mm}$ was recorded in 2005, and the maximum of $540 \mathrm{~mm}$ was recorded in 2010 . The rainfall in 2001 was more than $480 \mathrm{~mm}$. Despite the stabilization projects completed in the years following the 2001 failure of the Diezma landslide, a new retrogressive reactivation of the landslide occurred in 2010 (Figs.2d, 4) and damaged one of the four drainage barriers that are composed of drainage wells connected by drainage tubes. Several signs of landslide activity presently exist on the slope (Fig. 4), including recent ground cracks (Fig. 3a) and damage to the stabilization infrastructure (Fig. 3c, d) that is approximately six years old. The most recent data of 
retrogressive activity were collected on June 2013 from the crown area uphill of the 2010 landslide (Fig. 3b).

\section{ENGINEERING-GEOLOGICAL MODEL}

\subsection{Laboratory tests}

The geomechanical properties of the Diezma landslide mass were defined based on the laboratory test results from several samples obtained during the five borehole campaigns performed between 1999 and 2012. Most of the samples (i.e., 50 of 85) are from the Numidoide Formation and are characterized by a clay matrix with a variable compressibility (i.e., low to high) and by a coarse grained soil portion classified as GW to GC according to the Unified Soil Classification System (US Corps of Engineers, 1960) and ASTM (1983). Based on the laboratory tests, the unit weight is $19 \pm 2 \mathrm{kN} / \mathrm{m}^{3}$, the cohesion is approximately $46 \pm 23 \mathrm{kPa}$ and the peak internal friction angle is $26 \pm 6^{\circ}$. Nevertheless, due to the high variability of these parameter values, the engineering-geological model of the landslide mass was calibrated via back analysis by considering the geological setting of the slope and the triggering conditions of the Diezma landslide during its failure. The tests performed on the 19 samples from the Red Silt Formation show that it is composed of middle to low plasticity clays (CL) with a unit weight of $21 \pm 2 \mathrm{kN} / \mathrm{m}^{3}$, a cohesion of approximately $54 \pm 17 \mathrm{kPa}$ and an peak internal friction angle of $17 \pm 4^{\circ}$. No mechanical laboratory test results are available for the Green Clay (7 samples) and Black Schist (9 samples) Formations, but their unit weights are $21 \pm 1 \mathrm{kN} / \mathrm{m}^{3}$ and $23 \pm 1 \mathrm{kN} / \mathrm{m}^{3}$ respectively. This lack of data is not relevant for the 
proposed stability analysis because the Diezma landslide mass involves the deposits of the Numidoide Formation only.

\subsection{Geophysical investigations}

Three geophysical campaigns of seismic noise measurements were performed in the Diezma landslide slope in March and November 2012 and June 2013 to validate the geological model of the landslide and to better constrain the landslide volume. The basic principle for the interpretation of these geophysical measurements consists on the main resonance frequency $\left(f_{\text {res }}\right)$ of a soft soil column which overlay a stiff bedrock; in the specific case, the assumption is that the landslide mass itself represents a softened layer whose impedance contrast with the substratum is suitable for a local seismic amplification (Lenti and Martino, 2012). Under this assumption the expected amplification frequency should be related to the thickness $(\mathrm{H})$ as well as to the seismic wave velocity (Vs) of the landslide mass. If a theoretical 1D resonance model is assumed the expected $\mathrm{f}_{\text {res }}$ value corresponds to the ratio $\mathrm{Vs} / 4 \mathrm{H}$; nevertheless if $2 \mathrm{D}$ local amplification conditions exist they can significantly modify theoretical $f_{\text {res }}$ value (Semblat et al. 2002a, b). The measurement stations were equipped with a Guralp CMG-6TD three-component broadband seismometer. The 78 noise records have an average duration of 45 minutes and were collected during the day and night at the same locations. The seismic noise records were processed with the GEOPSY software (release 2.7.4; Whatelety et al., 2011) according to the SESAME Working Group (2004) standards. The horizontal over vertical spectral ratios (HVSR) were derived according to the approach of Nakamura (1989) as well as the HVSR azimuthal distribution. 
The results indicate that the noise measurements performed during the day are disturbed due to the traffic of the A-92 highway. Fig. 7 compares a six hour noise measurement performed at the same station during the day with one performed at night. A resonance peak is present at 4-5 Hz (Fig. 7a, b) from the HVSR during the night hours, while a second peak at 6-7 $\mathrm{Hz}$ appears during the daytime hours; the FFTs of the three components demonstrate that this peak is generated by the highway traffic (Fig. 7c). As a result, the amplitude of the HVSR measured during the day is significantly lower, and the local resonance is less evident, than the HVSR measured at night.

For this reason, only the records from the night hours (i.e., from 23.30 p.m. until 04.00 a.m.) were used in this study. The analysis of the noise records demonstrates that the landslide mass is characterized by a clear resonance frequency in the range of $4-5 \mathrm{~Hz}$ that is not present outside the landslide mass (Fig. 8). Moreover, the HVSR amplitudes generally decrease from the middle portion of the landslide mass toward the boundaries and are significantly reduced at the bottom of the slope (i.e., downhill from the retaining wall). This is most likely due to the lower impedance contrast of the rock fill behind the concrete wall that was constructed in 2001 to stabilize the roadway trench; moreover, considering the mid-slope position of the landslide mass and the slope inclination angle lower than $15^{\circ}$, topographic amplification/ deamplification effects can be neglected with respect to the resonance of the landslide mass itself (Lenti and Martino, 2012; 2013). Based on the peak frequencies retrieved from the noise and the landslide thickness from the engineering-geology model, the landslide mass should be characterized by a Vs value of approximately $300 \mathrm{~m} / \mathrm{s}$. This value is confirmed by Multichannel Analysis of Surface Waves (MASW) measurements performed specifically for 
this study in the landslide area. Based on the results of the noise measurements, a temporary accelerometer station was installed on the Rias slope to record earthquake events and to evaluate the local seismic response of the Diezma landslide mass.

\section{SLOPE STABILITY ANALYSIS}

\subsection{Back analysis}

The engineering-geology model of the Diezma landslide was calibrated using a back analysis of the large slope failure that occurred on 18 March 2001 by assuming a limit equilibrium condition $(\mathrm{SF}=1)$ at the time the landslide was triggered. This analysis was performed using the Janbu (1973) method, which is suitable for a sliding mechanism that is primarily characterized by a translational component. The longitudinal geological cross section AA' from Fig. 6 was selected because it is most representative of the Diezma landslide mechanism. The shape of the slope assumed for the back analysis corresponds to the slope after the excavation of the roadway trench at the foot of the slope but before the slope was reshaped in 2001. Because no data are available to reconstruct the groundwater flow at the triggering conditions, this study considered a pore water pressure distribution within the landslide mass for avoiding to predict a specific water flow net. At this aim, use was made of the Bishop coefficient $\left(\mathrm{r}_{\mathrm{u}}\right)$ which leads to a parametric study of the water pressure effect on the slope stability as well as to stability charts for landslide slopes (Michalowski, 2002) as widely used in geotechnical applications. In particular, this coefficient was assumed to be 
$25 \%$ higher than the mean admissible value (i.e., 0.22) computed for the geometry of the landslide mass. This assumption took into account that the landslide was triggered after 20 days with no rainfall following three months of very intense rainfall. The mechanical parameters of the landslide mass were calibrated using the back analysis; the results of this calibration indicate that the landslide mass has a residual internal friction angle of $12^{\circ}$, a residual cohesion of $4 \mathrm{kPa}$ and a wet unit weight of $21.4 \mathrm{kN} / \mathrm{m}^{3}$. These values agree with those obtained by Rodríguez-Peces et al. (2011a) from undisturbed samples of the Numidoide formation.

The spatial distribution of shear strength versus the forces acting on the landslide (Fig. 9a) demonstrates that the Diezma landslide is characterized by a neutral zone approximately 100 $\mathrm{m}$ wide that represents approximately $25 \%$ of the landslide mass. Moreover, using the mechanical parameters derived from the back analysis, a SF of 1.46 was obtained for the Rias slope in 2001 without considering water pressure (i.e., for $r_{u}=0$ ). For the same water pressure conditions and assuming the present shape of the slope as well as the effects of the anchors in the retaining wall, the SF is 1.52 (Fig. 9b).

\subsection{Conventional sensitivity analysis}

Based on the engineering-geological model and the strength properties obtained with the back analysis, a sensitivity study was performed on the effects of possible destabilizing actions for the present slope conditions by considering different values of the Bishop coefficient $r_{u}$ and different horizontal pseudostatic coefficients $\left(\mathrm{k}_{\mathrm{x}}\right)$, which can be related to seismic events using a conventional approach (Kramer, 1996). The critical values of the pseudostatic coefficients $\left(\mathrm{k}_{\mathrm{y}}\right)$ for different $\mathrm{r}_{\mathrm{u}}$ values are plotted in the stability chart of Fig. 9c where the 
pairs of $r_{u}$ and $k_{x}$ values for which SF is equal to 1.0 corresponding to an upper-bound curve that separates a stable-condition field (below the upper-bound line) from a unstable-condition one (above the upper-bound line).

The value of $r_{u}$ was varied across the range of the admissible values (i.e., $0-0.36$ ), and $k_{x}$ was varied +/- 50\% with respect to the PGA value expected for a return period of 475 years in the Diezma area (i.e., $0.07-0.14 \mathrm{~g}$ ) to take into account possible amplification/deamplification effects due to the local seismic response. The obtained results indicate that for a seismicity characterized by a return time lower than 475 years the Diezma landslide could become unstable for $r_{u}$ ranging up to the admissible value; nevertheless, in case of a seismic action corresponding to a return time of 475 years the landslide could be unstable also under almost dry conditions (i.e. very low $r_{u}$ values).

\subsection{Unconventional pseudostatic analysis}

Due to the lack of accelerometric records at the Diezma landslide site, an unconventional pseudostatic analysis was performed to evaluate the destabilizing effects of the seismic forces. The present shape of the slope was considered along geological cross section AA', and several distributions of the horizontal pseudostatic coefficient $\mathrm{k}_{\mathrm{x}}$ within the landslide mass $\left(\mathrm{k}_{\mathrm{x}}(\mathrm{x})\right)$ were considered. The seismic waves are represented by sine waves with different periods $\left(T_{m}\right)$ and phases $(\square)$ (Fig. 10); the phases varied from $0^{\circ}$ to $360^{\circ}$ from the crown of the landslide mass. Because the seismic wavelength $(\square)$ changes with the value of $T_{m}$, the $\left(\mathrm{k}_{\mathrm{x}}(\mathrm{x})\right)$ distributions are characterized by decreasing spatial variation with increasing $\mathrm{T}_{\mathrm{m}}$ (i.e., the wave's half-length becomes equal to the landslide length). For a null frequency (i.e., an 
infinite seismic wave period), the assumed conditions are theoretically identical to pseudostatic conditions ( $\mathrm{k}_{\mathrm{x}}$ is equal for all the slices considered in the analysis).

In particular, the sine waves cause accelerations of $0.07 \mathrm{~g}$ and $0.14 \mathrm{~g}$; these values bound the range of expected PGA values for a return period of 475 years, and they are characterized by values of $\mathrm{T}_{\mathrm{m}}$ between 2 and $0.33 \mathrm{~s}$ (i.e., corresponding to seismic wavelengths within the Diezma landslide mass from 100 to $600 \mathrm{~m}$ ). As shown in Table 2, different possible seismic wave phases were assumed for each considered PGA and $T_{m}$ value to condition the spatial distribution of the sine wave peaks within the landslide mass. Different distributions of water pressure were also considered by varying the $r_{u}$ coefficient from 0 to 0.36 ).

The distributions of $\operatorname{SF}\left(\square, f_{m}\right.$ ), which represent SF vs. sine phase ( $\square$ ) and the characteristic frequency $\left(f_{m}=1 / T_{m}\right)$, are reported in Fig. 11 and Fig. 12 for PGAs of $0.07 \mathrm{~g}$ and $0.14 \mathrm{~g}$, respectively. These distributions are obtained for the range of admissible $r_{u}$ values. The obtained $\operatorname{SF}\left(\square, \mathrm{f}_{\mathrm{m}}\right)$ distributions demonstrate that the stability of the Diezma landslide is strongly influenced by the both the sine wave phase and frequency as the $\operatorname{SF}\left(\square, f_{m}\right)$ values decrease below $1 \mathrm{~Hz}$. The minimum values are reached for $\square$ values in the range $0-90^{\circ}$, while the maximum values are found in the supplementary range of $\square$ values (i.e., $180^{\circ}-$ $\left.270^{\circ}\right)$. The $\operatorname{SF}\left(\square, f_{m}\right)$ distributions show that the stability of the slope is controlled more by the phase than by the frequency of the sine wave. Several $\operatorname{SF}(\square)$ vs. $r_{u}$ distributions were computed for each value of $T_{m}$ and PGA. The minimum $S F(\square)$ vs. $r_{u}$ distribution was selected to represent the most critical dynamic stability condition for the slope. The selected $\operatorname{SF}(\square)$ values were expressed as a function of the sine frequencies for each $r_{u}$ value. The results of 
this analysis are shown in Fig. 13 and show that the $\operatorname{SF}(\square)$ values of the Diezma landslide increase significantly with increasing frequencies from 0 (i.e., conventional pseudostatic conditions) to $1 \mathrm{~Hz}$. In particular, for a $0.14 \mathrm{~g}$ sinusoid amplitude, the critical conditions $(\mathrm{SF}(\square)=1)$ correspond to $\mathrm{f}_{\mathrm{m}}$ values between 0.5 and $1.0 \mathrm{~Hz}$ for $\mathrm{r}_{\mathrm{u}}$ values between 0 and 0.36 , while for a $0.07 \mathrm{~g}$ sine waves amplitude, the critical conditions correspond to $f_{m}$ values ranging from 0 to $1.0 \mathrm{~Hz}$ for $\mathrm{r}_{\mathrm{u}}$ values between 0 and 0.36 . The comparison with the SF values derived by a conventional pseudostatic approach (i.e. corresponding to the $\mathrm{f}_{\mathrm{m}}=0 \mathrm{~Hz}$ values in the graph of Fig.13) shows that they are systematically lower with respect to the ones derived by the here proposed unconventional approach for each assumed $r_{u}$ and PGA value. More in particular, in the case of the Diezma landslide, the SF values are significantly underestimated if the characteristic frequency of the earthquake is higher than $1 \mathrm{~Hz}$. This means that higher $r_{u}$ values should be assumed for reaching unstable conditions due to a seismic action corresponding to a return time of 475 years if the here proposed unconventional approach is applied.

\subsection{Evaluation of co-seismic displacements}

To provide a preliminary estimate of the co-seismic displacements expected for the Diezma landslide for earthquakes with different characteristic periods $\left(\mathrm{T}_{\mathrm{m}}\right)$ and Arias Intensities (AI) relationships, the relationships proposed by Lenti and Martino (2013) and restituted by numerically-derived abacuses were used. These relationships express the dynamic co-seismic displacements as a function of a landslide mass to the characteristic periods $T_{\mathrm{s}}$ and $\mathrm{T}_{1}$ that are related to its thickness and length, respectively, as these geometrical features control the 1D resonance (Rathje and Bray, 2000) and the movement of the landslide mass during seismic 
shaking (Hutchinson, 1994). The theoretically optimum values of the $T_{s} / T_{m}$ and $T_{l} / T_{m}$ ratios for the maximum co-seismic displacements are 1.0 and 0.5 , respectively. The most representative abacuses by Lenti and Martino (2013) were selected: i) assigning a translational mechanism and a critical pseudostatic coefficient equal to $0.1 \mathrm{~g}$ representative for the critical pseudostatic coefficient of the Diezma landslide under dry conditions (Fig.9c); ii) assuming a landslide slope inclination of less than $15^{\circ}$ based on the Diezma landslide topography; and iii) considering AI values ranging from 0.01 up to $1.0 \mathrm{~m} / \mathrm{s}$. The $\mathrm{T}_{\mathrm{m}}$ values were varied in the same range assumed for the sine waves in the unconventional pseudostatic analysis (i.e., $0.5-3.0 \mathrm{~Hz}$ ). The values of $\mathrm{T}_{1}$ and $\mathrm{T}_{\mathrm{s}}$ computed for the Diezma landslide are $1.33 \mathrm{~s}$ and $0.20 \mathrm{~s}$, respectively; they are based on a landslide length of $400 \mathrm{~m}$, an average Vs of $300 \mathrm{~m} / \mathrm{s}$ and an average landslide thickness of $15 \mathrm{~m}$ that were derived from both the engineering-geological model of the landslide and the outputs of the geophysical investigations. Based on these computed characteristic periods, the maximum co-seismic displacements should theoretically be expected for earthquakes with $\mathrm{T}_{\mathrm{m}}$ values of $2.66 \mathrm{~s}$ and $0.20 \mathrm{~s}$ by considering $\mathrm{T}_{\mathrm{s}} / \mathrm{T}_{\mathrm{m}}$ and $\mathrm{T}_{1} / \mathrm{T}_{\mathrm{m}}$ ratios equal to 1.0 and 0.5 , respectively. The co-seismic displacements were derived according to the literature abacuses and are summarized in Table 3; the maximum estimated values are approximately $2 \mathrm{~m}$ for AI values on the order of $1 \mathrm{~m} / \mathrm{s}$, which corresponds to earthquakes with $T_{m}$ values close to $1 \mathrm{~s}$. These results demonstrate that the Diezma landslide can be re-activated by earthquakes since sliding displacements of the landslide mass up to a meter-scale can be induced by the seismic shaking for AI ranging from 0.01 up to $1 \mathrm{~m} / \mathrm{s}$. Based on the empirical correlation between PGA and AI proposed by Lenti et al. (2012) and derived by considering 6850 accelerometric records from the European Strong Motion database (Ambraseys et al., 2004), the on-line ITalian ACcelerometric Archive 
(ITACA - http://itaca.mi.ingv.it/ItacaNet/) and the K-NET on-line database (http://www-knet.bosai.go.jp/k-net/index.en.shtml), an average PGA of 0.05g should be expected for a AI of $0.01 \mathrm{~m} / \mathrm{s}$, i.e. comparable with the PGA expected at Diezma for a return period of 475 years, while a PGA of $0.5 \mathrm{~g}$ should be expected for a AI of $1 \mathrm{~m} / \mathrm{s}$.

The relative contributions of the $T_{s} / T_{m}$ ratio (i.e., related to the average thickness of the landslide mass and consequently to its $1 \mathrm{D}$ resonance) and of the $T_{1} / T_{m}$ ratio (i.e., related to the landslide length and consequently to the $2 \mathrm{D}$ seismic wave propagations within the mass) to the co-seismic displacements were evaluated based on the percentage difference of each ratio from the theoretical values that provide the maximum displacements. The calculated percentage contributions are almost equal if the $T_{m}$ is approximately of $1 \mathrm{~s}$ while the $2 \mathrm{D}$ effects have a prevalent contribution to the co-seismic displacements (i.e. related to the $T_{\mathrm{s}} / \mathrm{T}_{\mathrm{m}}$ ratio) for increasing values of $\mathrm{T}_{\mathrm{m}}$.

\section{CONCLUSIONS}

This study presents an unconventional analysis carried out by a novel pseudostatic approach to evaluate the sensitivity of the Diezma landslide mass (Granada, Spain) to the characteristic frequencies and the phases of a seismic input. A high-resolution engineering-geological model of the landslide was based on correlations between numerous borehole logs as well as field surveys and geophysical investigations. The model provided structural constraints on the landslide mechanism. Moreover, the well documented triggering conditions that occurred on 18 March 2001 and during the later reactivations of the landslide until 2010 made it possible to constrain a back analysis under limit equilibrium conditions to calibrate the geomechanical properties of the landslide mass. According to a sensitivity analysis of the external actions 
(i.e. distributions of pore pressure and earthquake) low stability conditions generally result for the Diezma landslide, which are consistent with the reactivation of the landslide over the last decade. The performed analyses on the Diezma landslide slope demonstrate a high sensitivity of the landslide mass to seismic waves whose main frequency content is lower than $1 \mathrm{~Hz}$. In these conditions, the stability conditions can significantly vary depending on the frequency values and the earthquake-induced displacements, evaluated by numerically-derived relationships, reach the maximum expected values (up to $2 \mathrm{~m}$ ). These earthquake-induced effects are mainly due to the $1 \mathrm{D}$ resonance due to the mass thickness if the characteristic period of the input $\left(T_{m}\right)$ is close to $1 \mathrm{~s}$ while they mainly depend on its length for increasing $\mathrm{T}_{\mathrm{m}}$ values.

Because the preliminary evaluations presented here indicate that significant seismic effects can be expected in severe earthquake scenarios, future analyses will focus on earthquake measurements at the Diezma landslide site as well as on dynamic analyses to better constrain the co-seismic displacements that can affect the landslide and cause damage to the A-92 highway.

\section{AKNOWLEDGEMENTS}

The authors wish to thank Alessandra Noviello, Fabiola Tammaro and Ester Vilaplana for their contribution to the field surveys and to the slope stability analyses and the Municipality of Diezma for the technical support in the site investigations; Dr. Carlos Sanz de Galdeano (Univ. Granada) and Dr. Francisco García-Tortosa (Univ. Jaén) for their revision of field works and maps. The Authors also wish to thank Bill Murphy and another anonymous referee for the useful suggestion provided for improving the paper. This research was performed in the framework of the cooperation agreements between the Dpt. di Scienze della Terra of the University of Rome "Sapienza" (Italy) and the Dpt. Ciencias de la Tierra y del Medio 
Ambiente of the University of Alicante (Spain) and between the "Centro di Ricerca per i Rischi Geologici (CERI)" of the University of Rome "Sapienza" (Italy) and the "Institut Français des Sciences et Technologies des Transports, de l'Aménagement et des Réseaux" (IFSTTAR of Paris - France).

\section{REFERENCES}

Ambraseys, N. N., J. Douglas, R. Sigbjörnsson, C. Berge-Thierry, P. Suhadolc, G. Costa, and M. P. Smit (2004). Dissemination of European strong-motion data, volume 2, in Proc. 13th World Conference on Earthquake Engineering, Vancouver, B.C., Canada, 1-6 August 2004.

ASTM (1983) - Test designation D3283: Standard practice for classification of soils and soil aggregate mixtures for highway construction purpose. Vol. 04.08. ASTM Philadelphia, USA. 
Azañón, J.M., Azor, A., Cardenal, J.F., Delgado García, J., Delgado, J., Gómez-Molina, A., López-Chicano, M., López-Sánchez, J.M., Mallorqui-Franquet, J.J., Martín W., Mata de Castro, E., Mateos, R.M., Nieto, F., Peña, J.A., Pérez-García. J.L., Puerma M., RodríguezFernández, J., Teixidó, T., Tomás, R., Tsige, M., Yesares, J., 2006. Estudio sobre la predicción y mitigación de movimientos de ladera en vías de comunicación estratégicas de la Junta de Andalucía. Informe final. Instituto Andaluz de Ciencias de la Tierra,CSICUGR (ed), Granada (Spain), 380 p.

Azañón, J.M., Azor, A., Yesares, J., Tsige, M., Mateos, R.M., Nieto, F., Delgado, J., LópezChicano, M., Martín, W., Rodríguez-Fernández, J., 2010. Regional-scale high plasticity clay-bearing formation as controlling factor on landslides in Southeast Spain. Geomorphology 120, 26-37.

Benito, M.B., Navarro, M., Vidal, F., Gaspar-Escribano, J., Garcia-Rodriguez, M.L., Martinez-Solares, J.M., 2010. Seismic hazard assessment in the region of Andalusia (Sothern Spain). Bull Earthquake Eng 8, 739-766.

Bourdeau, C., Havenith, H.B., 2008. Site effects modeling applied to the slope affected by the Suusamyr earthquake (Kyrgyzstan, 1992). Engineering Geology 97, 126-145.

Bozzano, F., Lenti, L., Martino, S., Paciello, A., Scarascia Mugnozza, G., 2008. Selfexcitation process due to local seismic amplification responsible for the reactivation of the Salcito landslide (Italy) on 31 October 2002 Journal of Geophysical Research 113, B10312, doi:10.1029/2007JB005309.

Bozzano, F., Lenti, L., Martino, S., Paciello, A., Scarascia Mugnozza, G., 2011. Evidences of landslide earthquake triggering due to self-excitation process. International Journal of 
Earth Sciences 100, 861-879. DOI. 10.1007/s00531-010-0514-5.

Consejería de Obras Públicas y Transportes Junta de Andalucia, 2001. Corrección de deslizamiento en autovía A-92P.K. 272+700 M.I. en Diezma (Granada). Junta de Andalucía.

Cruden, D.M, Varnes, D.J., 1996. "Landslide types and processes", In: Turner AK, Schuster RL, (eds.) Landslides: investigation and mitigation. Transportation Research Board, Spec. Report 247, National Research Council, National Academy Press, Washington, DC, 3675.

Danneels, G., Bourdeau, C., Torgoev, I., Havenith H.B., 2008) Geophysical investigation and dynamic modeling of unstable slopes: case-study of Kainama (Kyrgyzstan). Geophysical Journal International, 175(1), 17-34.

Del Gaudio, V., Wasowski, J. 2007. Directivity of slope dynamic response to seismic shaking. Geophys. Res. Lett 34, L12301, doi:10.1029/2007GL029842.Delgado, J., Garrido, J., López-Casado, C., Martino, S., Peláez, J.A., 2011a. On far field occurrence of seismically induced landslides. Engineering Geology 123, 204-213. DOI: doi:10.1016/j.enggeo.2011.08.002.

Delgado, J., Peláez, J.A., Tomás, R., García-Tortosa, F.J., Alfaro, P., López Casado, C., 2011b. Seismically-induced landslides in the Betic Cordillera (S Spain). Soil Dynamics and Earthquake Engineering 31, 1203-1211.

Fundación Agustín de Betancourt, 2001a. Informe sobre el deslizamiento de Diezma (A-92) y las soluciones para estabilizarlo. Madrid. $60 \mathrm{p}$. 
Fundación Agustín de Betancourt, 2001b. Informe complementario sobre el deslizamiento de Diezma (A-92) y las soluciones para estabilizarlo. Madrid. 18 p.

Garcia-Dueñas, V., Navarro-Vila, F., Perez-Rojas, A., Gonzals-Donoso, J.M., MartinezGallego, J., 1980. Mapa Geológica de España, escala 1:50.000, hoja 1010 "La Peza". Instituto Geológico y Minero de España.

Garrido, J. (1992). Taludes inestables de la autovía Sevilla-Granada-Baza (A-92) en la provincia de Granada". III Congreso Geológico de España; Vol 2, pag. 355-358. Salamanca.

Hutchinson, J.N., 1994. Some aspects of the morphological and geotechnical parameters of landslides, with examples drawn from Italy and elsewhere. Geologica Romana 30, 1-14.

Hynes-Griffin, M.E., Franklin, A.G. 1984. Rationalizing the Seismic Coefficient Method, Miscellaneous Paper GL-84-13. Department of the Army, Waterways Experiment Station, Vicksburg, MS.IECA, Instituto de Estadística y Cartografía de Andalucía, 2013. http://www.juntadeandalucia.es/institutodeestadisticaycartografia/lineav2/web/. Last accessed September 2013.

Janbu, N., 1973. Slope stability computation. In Embankment dam engineering. Edited by R.C. Hirschfeld and S.J. Poulos. John Wiley and Sons, New York, pp. 47-86.

Jibson, W.J., 2012. Modelling of triggering landslides during earthquakes. In J. J. Clague and D. Stead eds.: Landslides: Types, Mechanisms and Modeling. Cambridge University Press, 196-206.

Kramer, S.L., 1996. Geotechnical Earthquake Engineering. Prentice Hall, Upper Saddle 
River, NJ, 653 pp.

Lenti, L., Martino, S., Rinaldis, D. (2012). LEMA_DES equivalent signals derived from the accelerometric records of the European database. In: 15 World Conference on Earthquake Engineering. Lisboa, 24-28 September 2012, paper 2414 (on-line published http://www.iitk.ac.in/nicee/wcee/article/WCEE2012_2414.pdf).

Lenti, L., Martino, S., 2012. The interaction of seismic waves with step-like slopes and its influence on landslide movements. Engineering Geology 126, 19-36.

Lenti, L., Martino, S., 2013. A Parametric Numerical Study of Interaction between seismic waves and landslides for the evaluation of the susceptibility to seismically induced displacements. Bulletin of the Seismological Society of America 103(1), 33.56.

Marcuson, W.F., 1981. Moderator's report for session on "Earth dams and stability of slopes under dynamic loads. Proc. Int. Conf. Recent Advances in Geotechnical Earthquake Engineering and Soil Dynamics, St. Louis, Missouri, 3:1175.

Martino, S., Scarascia Mugnozza, G., 2005. The role of the seismic trigger in the Calitri landslide (Italy): historical reconstruction and dynamic analysis. Soil Dynamics Earthquake Engineering 25, 933-950.

Michalowsky, R.L., 2002. Stability Charts for Uniform Slopes. Journal of Geotechnical and Geoenvironmental Engineering, 128:4, 351- 355, doi: 10.1061/(ASCE)1090-0241.

Nakamura, Y., 1989. A method for dynamic characteristics estimations of subsurface using 683 microtremors on the ground surface, Quarterly Rept. RTRI Japan 30, 25-33.

Newmark, N.M., 1965. Effects of earthquakes on dams and embankments. Geotechnique 
15(2), 139-159.

Ofiteco, 2000. Estudio geotécnico y análisis del agrietamento en el desmonte del P.K. 272,7 de la A-92, en la zona de Rias. Término municipal de Diezma (Granada). Junta de Andalucía.

Pintor, J. J., and Azor, A., 2006. The Güevéjar landslide: A case study of slope instability triggered by earthquakes, Geogaceta 40, 287-290.

Rathje, E.M., Bray, J.D., 2000. Nonlinear Coupled Seismic Sliding Analysis of Earth Structures. Journal of Geotechnical and Geoenvironmental Engineering, ASCE 126(11), 1002-1014.

Rodríguez-Peces, M.J., Azañón, J.M., García-Mayordomo, J., Yesares, J., Troncoso, E., Tsige, M., 2011a. The Diezma landslide (A-92motorway, Southern Spain): history and potential for future reactivation. Bull Eng Geol Environ 70, 681-689.

Rodríguez-Peces, M.J., García-Mayordomo, J., Azañón, J.M., Insua-Arévalo, J.M., JiménezPintor, J., 2011b. Constraining pre-instrumental earthquake parameters from slope stability back-analysis: Paleoseismic reconstruction of the Güevéjar landslide during the 1st November 1755 Lisbon and 25th December 1884 Arenas del Rey earthquakes. Quaternary International, 242, 76-89.

Sanz de Galdeano, C., Delgado, F. and López Garrido, A.C., 1995. Alpujarride and Malaguide units to the NE of Granada (Bétic Cordillera). Geogaceta, 18 (1995), 27-29.

Seed, H.B., Martin, G.R., 1966. The seismic coefficient in earth dam design. J. Soil Mech. and Found. Div., ASCE, 92(SM3):25-58. 
Semblat, J. F., Dangla, P., Kham, M. and Duval A. M., 2002a. Seismic site effects for shallow and deep alluvial basins: in-depth motion and focusing effect, Soil Dynamics and Earthquake Engineering, 22(9), 849-854.

Semblat, J. F., Duval, A.M. and Dangla P., 2002b. Seismic site effects in a deep alluvial basin: numerical analysis by the boundary element method, Computers and Geotechnics, 29(7), 573-585.

Sepulveda, S. A., Murphy, W., Jibson, R. W., and Petley, D. N., 2005a. Seismically induced rock slope failures resulting from topographic amplification of strong ground motions: The case of Pacoima Canyon, California, Eng. Geol., 80, 336-348.

Sepulveda, S. A., Murphy, W., and Petley, D. N. 2005b. Topographic controls on coseismic rock slides during the 1999 Chi-Chi earthquake, Taiwan, Q. J. Eng. Geol. Hydrogeol., 38, 189-196.

SESAME Working Group, 2004. Guidelines for the implementation of the h/v spectral ratio tecnique on ambient vibration measurements, processing and interpretation. http://sesamefp5.obs.ujf-grenoble.fr/Delivrables/Del-D23-HV_User_Guidelines.pdf.

Sherard, J.L., 1967. Earthquake considerations in earth dam design. J. Soil Mech. and Found. Div., ASCE, 93(SM4):377-401.

Stewart J.P., Blake, T.F., Hollingsworth, R.A., 2003. A Screen Analysis Procedure for Seismic Slope Stability. Earthquake Spectra 19 (3), 697-712.

Terzaghi, K., 1950. Mechanics of landslides, Engineering geology (Berkley) volume. Geological Society of America; 1950. 
US Corps of Engineers, 1960. The Unified Soil Classification System. Waterways Exp. Est. Viksburg, Miss.

Wathelet, M., Orhnberger, M., Köhler, A., Cornou, C., 2011. Geophysical signal database for noise array processing (GEOPSY - release 2.7.4). Free download available at the website: http://www.geopsy.org/download.php.

Yesares, J., Arocha, J., Azañón, J.M., Azor, A., Diaz-Losada, E., Lopez-Chicano, M., Martin, W., Nieto, F., Rodriguez Fernandez, J., Garrido-Manrique, J., 2004, Factores condicionantes en el deslizamiento de Diezma (Granada, España). In. G. Benito \& Diez Herrero eds. Riesgos naturales y antropicos en Geomorfologia (Actas de la VIII Reunion Nacional de Geomorfologia, Toledo, 22-25 de Septiembre de 2004). SEG y CSIG, Madrid, 445-450.

\section{CAPTION TO FIGURES AND TABLES}

Fig. 1 - Location and aerial view of the Diezma landslide.

Fig. 2 - Photos showing the activity of the Diezma landslide and the main interventions performed to stabilize the landslide mass: a) the first landslide, which occurred in October 1990, viewed from the roadway trench of the A-92 highway; b) a large failure that occurred on 18 March 2001; view of the landslide toe involving the A-92 highway; c) a large failure 
that occurred on 18 March 2001; view of the landslide crown area involving the old road $\mathrm{CN}$ 342 to Granada; d) aerial view of the last reactivation of the Diezma landslide, which occurred in 2010; e) excavation of the ditches within the landslide mass in 2001-2002; f) installation of the drainage wells within the landslide mass in 2001-2002; g) anchored retaining wall and block-supported backfill constructed at the bottom of the landslide slope; h) retaining wall foundation.

Fig. 3 - Evidence of the activity of the Diezma landslide on the Rias slope: a) ground cracks along the old national road to Granada CN-342; b) ground cracks in the crown area of the last reactivated landslide volume observed in June 2013; c) damage to the drainage ditches; d) damage observed in some of the drainage wells.

Fig. 4 - Geological map of the Rias slope area. The legend also refers to the geological cross section in Fig. 6: 1) Diezma landslide mass; 2) slope debris; 3) Numidoide Formation; 4) Limestones of the Dorsal domain (Eocene); 5) Formations of the Maláguide domain (Devonian - Triassic); 6) 1998 ground cracks; 7) 2001 perimeter of the Diezma landslide; 8) 2010 reactivation of the Diezma landslide; 9) ground cracks; 10) fault deduced from borehole logs; 11) road; 12) track; 13) retaining wall anchored and founded on piles; 14) drainage wells; 15) borehole; 16) inclinometer; 17) house; 18) spring.

Fig. 5 - Geological formations outcropping on the Rias slope: a) deposits of the Numidoide Formations; b) Red Silt Formation of the Maláguide domain in the landslide debris outcropping along the trench of a drainage channel uphill from the road to the Hotel Señorio 
del Rias; c) Green Clay Formation of the Malaguide domain; d) Black Schist Formation of the Maláguide domain.

Fig. 6 - Geological cross sections along traces $\mathrm{AA}^{\prime}, \mathrm{BB}^{\prime}$ and $\mathrm{CC}^{\prime}$ in Fig. 4: 1) landslide mass; 2) Numidoide Formation; 3) Formations of the Maláguide domain; 4) inclinometers; 5) drainage well; 6) boreholes; 7) sliding surface; 8) fault deduced from borehole logs.

Fig. 7 - Comparison between six-hour noise measurements at the Rias slope performed at night and during the day. a) HV-rotate GEOPSY diagram, i.e. showing the azimuthal distribution of the HVSR values; b) HVSR amplitude vs. frequency (the dashed lines indicate the average values plus and minus the standard deviation); c) FFT of the three components of the noise records processed according to the SESAME (2004) standards.

Fig. 8 - Map of the noise measurements performed in the Rias slope in June 2013 and processed with the GEOPSY software. HV-rotate plots are shown for each measurement point (all the results are for night measurements, i.e., performed between 23.30 p.m. and 04.00 a.m.).

Fig. 9 - Results of the slope stability analysis under limit equilibrium conditions: a) spatial distribution of the shear strength and the forces for the pre-landslide slope and for the present slope; b) sensitivity analysis of the pore water pressure distribution in terms of SF vs. $r_{u}$ for the pre-landslide slope and for the present slope; c) results of the conventional pseudostatic analysis for the present slope expressed in terms of $k_{y}$ vs. $r_{u}$.

Fig. 10 - Distributions of $\mathrm{k}_{\mathrm{x}}(\mathrm{x})$ within the landslide mass for different amplitudes (PGA), periods $\left(T_{m}\right)$, phases $(\square)$ and corresponding wavelengths $(\square)$ of the sine signals. The 
geological cross-section is along the same trace of Fig. 6: 1) landslide mass; 2) Numidoide Formation; 3) Formations of the Maláguide domain; 4) sliding surface; 5) faults deduced from borehole logs; 6) freatic water surface. The numbers of the slices used for the limit equilibrium analysis are also given, and the pore water pressure distribution for $r_{u}=0.2$ is shown.

Fig. $11-\operatorname{SF}\left(\square \square f_{m}\right)$ distributions from the unconventional pseudostatic analysis for a PGA of $0.07 \mathrm{~g}$ and $\mathrm{r}_{\mathrm{u}}$ values varying from 0 to 0.36 .

Fig. $12-\operatorname{SF}\left(\square \square f_{m}\right)$ distributions from the unconventional pseudostatic analysis for a PGA of $0.14 \mathrm{~g}$ and $\mathrm{r}_{\mathrm{u}}$ values varying from 0 to 0.36 .

Fig. 13 - Results of the unconventional pseudostatic analysis reported in terms of minimum $\mathrm{SF}(\square)$ vs. frequency for $\mathrm{r}_{\mathrm{u}}$ values varying from 0 to 0.36 and for PGAs of 0.07 and $0.14 \mathrm{~g}$.

Table 1 - Summary of the evolution of the Diezma landslide slope over the past several decades and of the main interventions used to restore the damaged infrastructure and to stabilize the slope.

Table 2 - Example of the $\mathrm{k}_{\mathrm{x}}(\mathrm{x})$ distributions obtained for different sinusoidal signals, i.e., characterized by different amplitudes (PGA), periods $\left(T_{m}\right)$ and phases $(\square)$ corresponding to different wavelengths $(\square)$; the resulting SF values computed for $r_{u}$ values between 0 and 0.36 are also reported. 
Table 3 - Co-seismic displacements expected for the Diezma landslide as a function of the characteristic period ratios $\left(\mathrm{T}_{\mathrm{s}} / \mathrm{T}_{\mathrm{m}}\right.$ and $\left.\mathrm{T}_{1} / \mathrm{T}_{\mathrm{m}}\right)$ and of the AI values derived using the relationships proposed by Lenti and Martino (2013). 


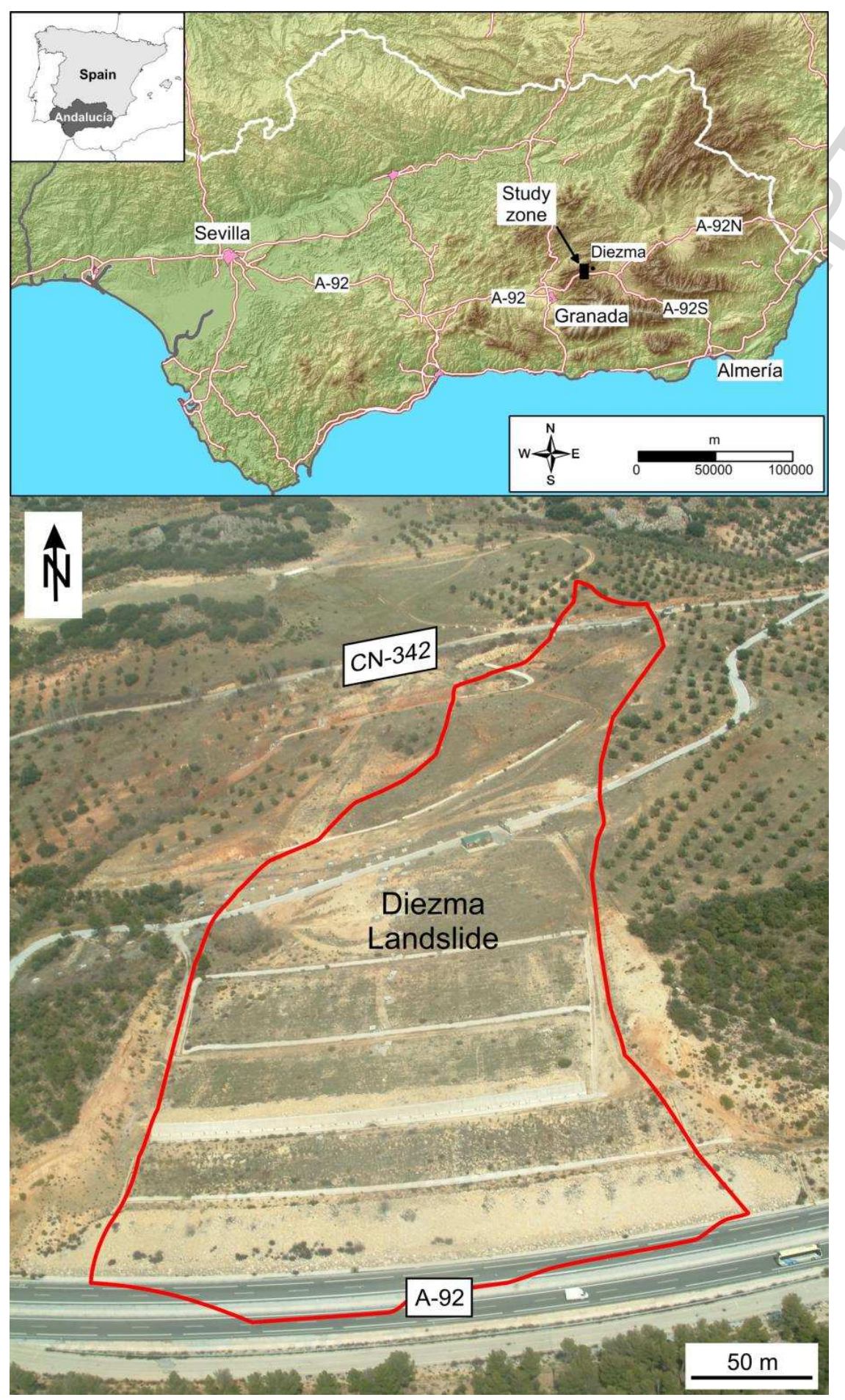

Figure 1 

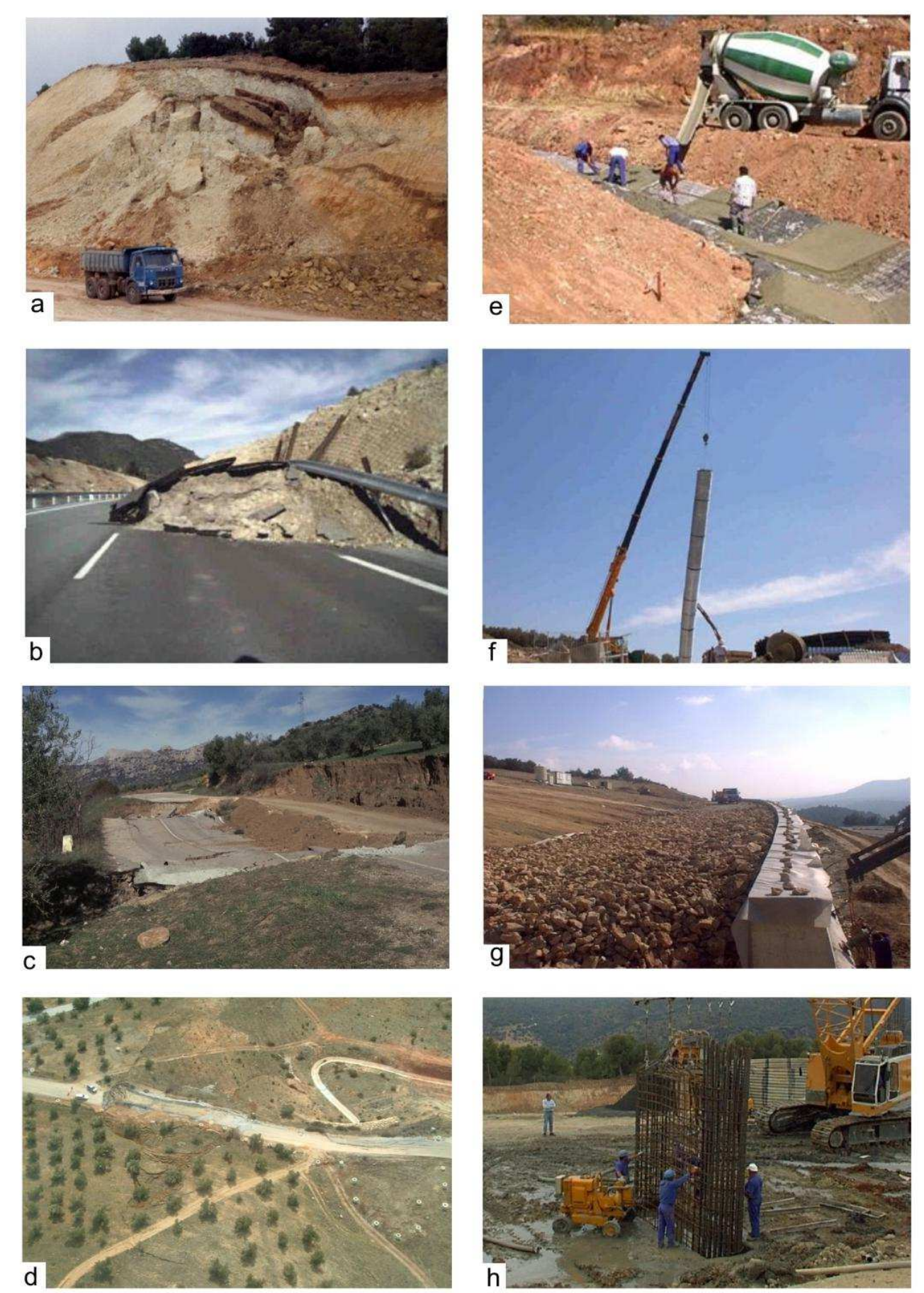

Figure 2 


\section{ACCEPTED MANUSCRIPT}
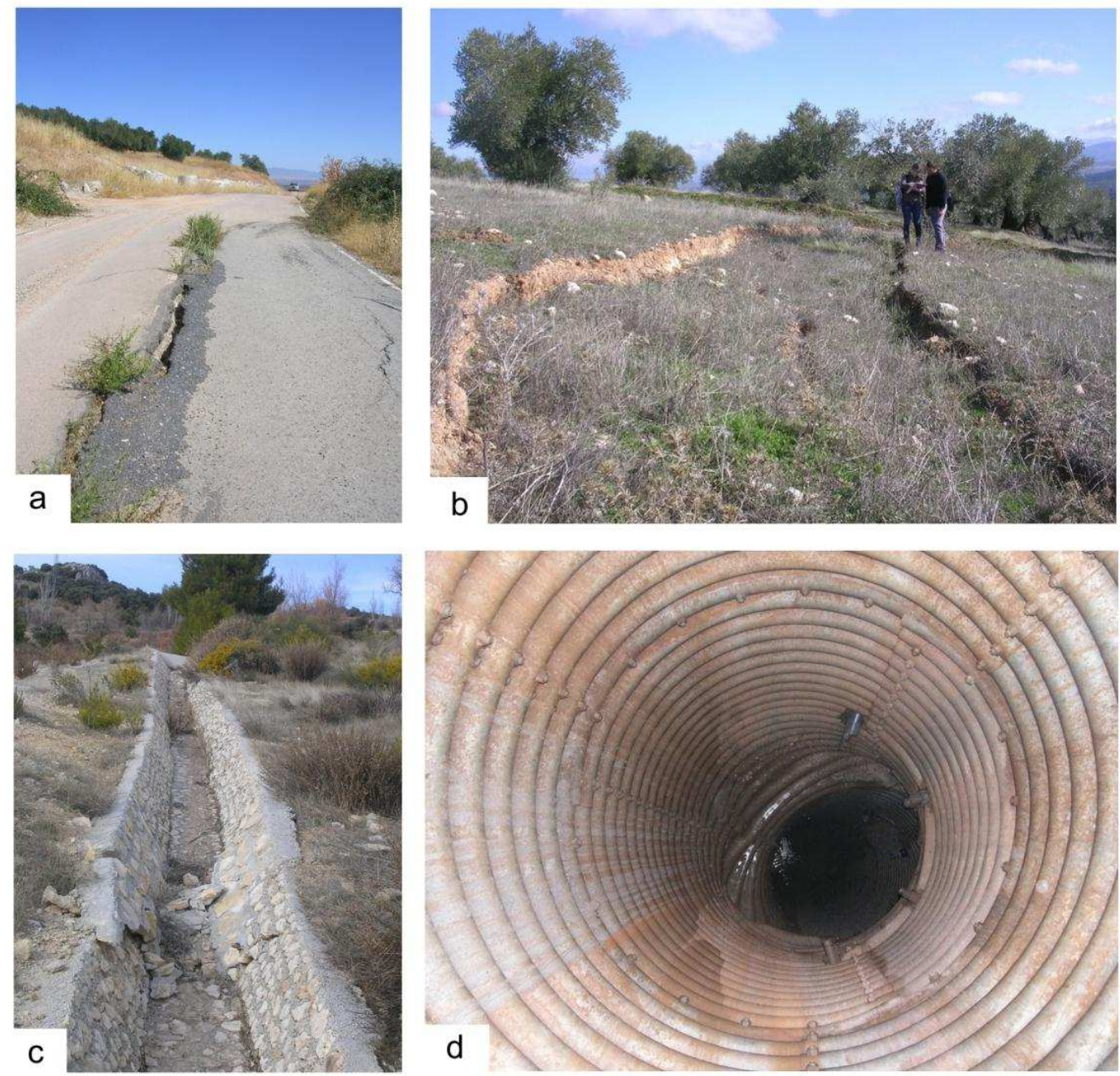

Figure 3

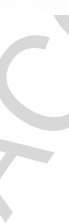




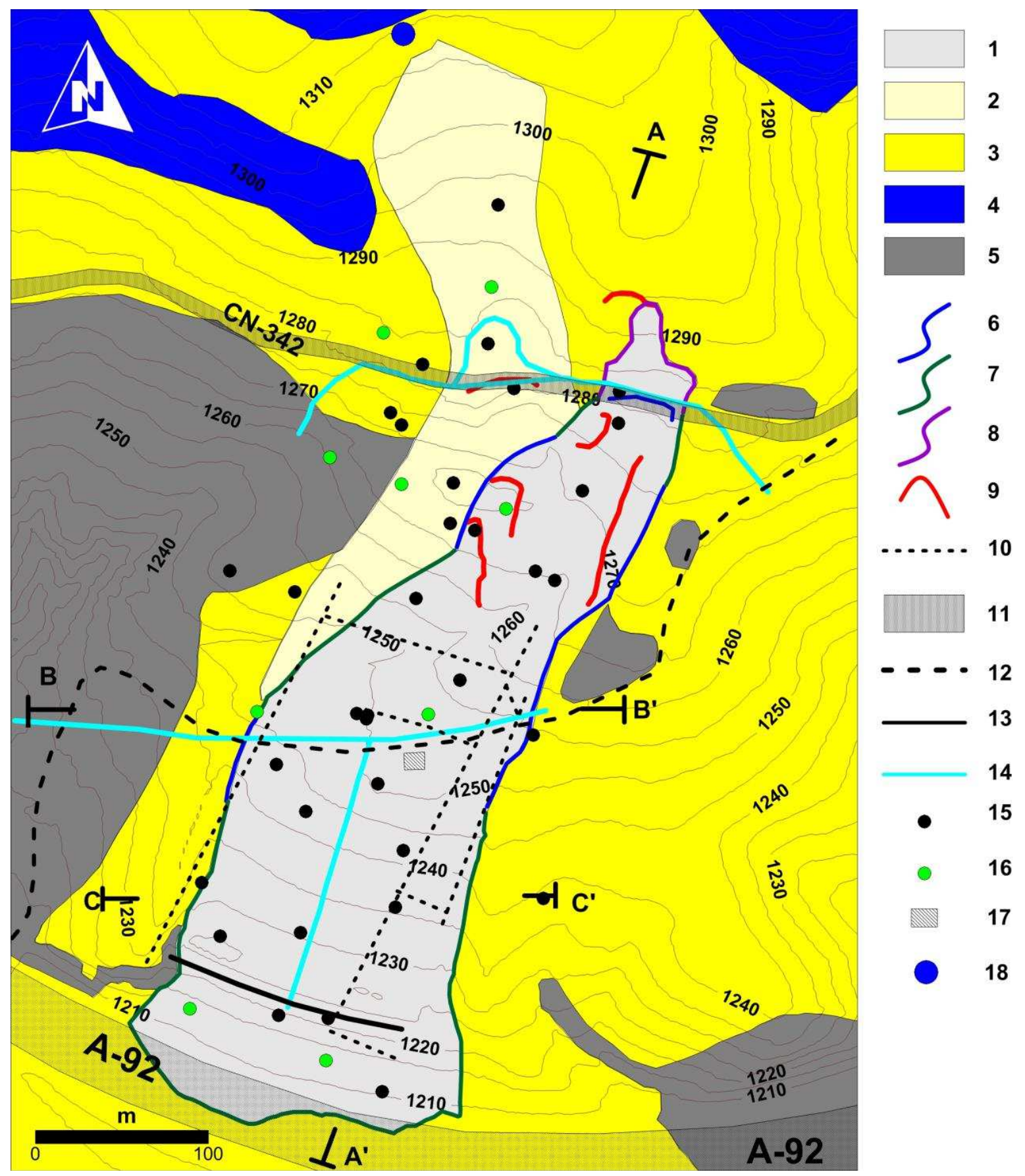

Figure 4 


\section{ACCEPTED MANUSCRIPT}
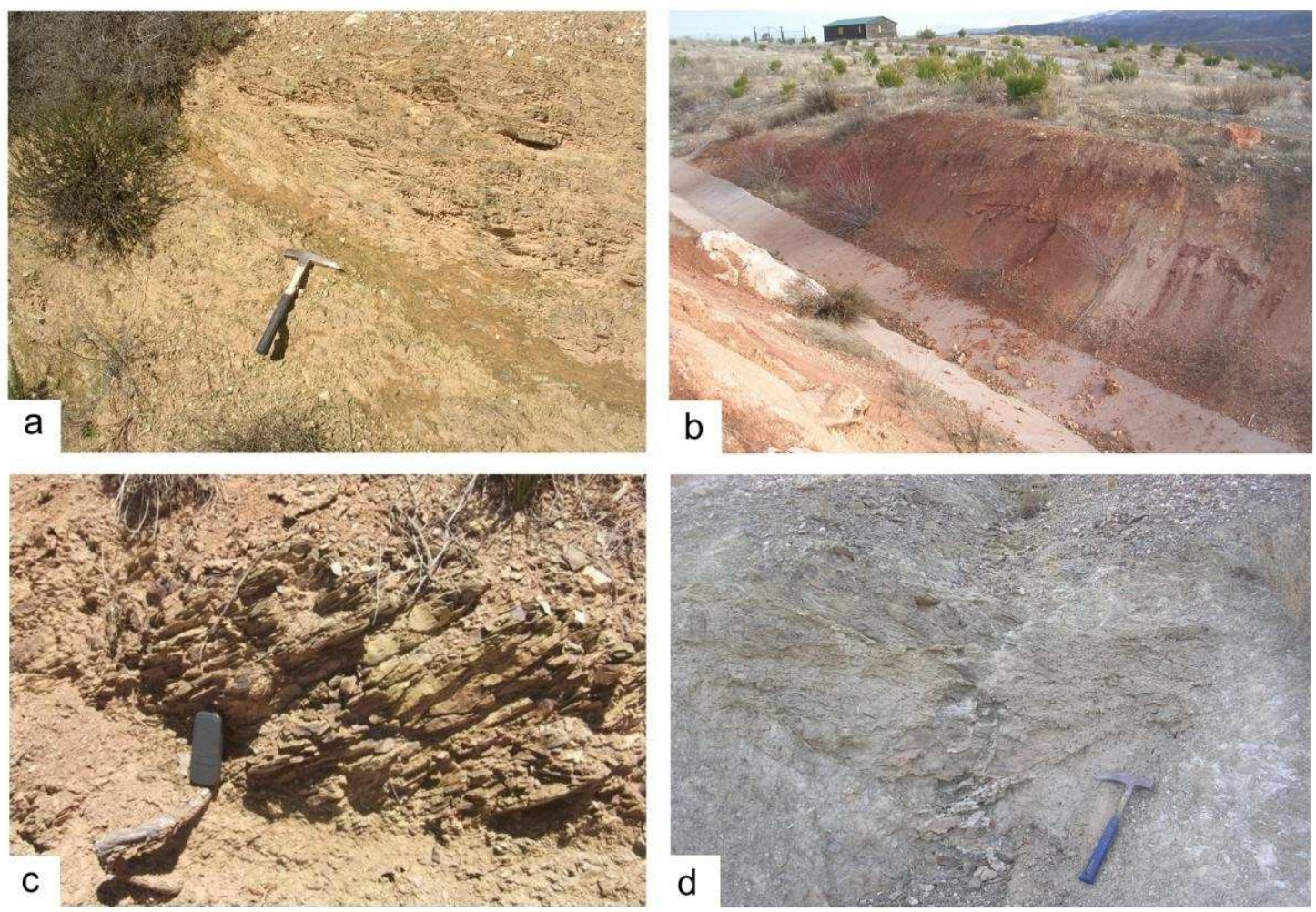

Figure 5

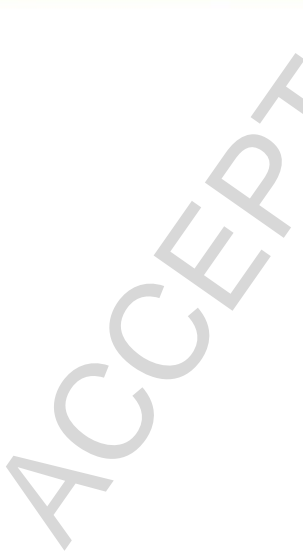




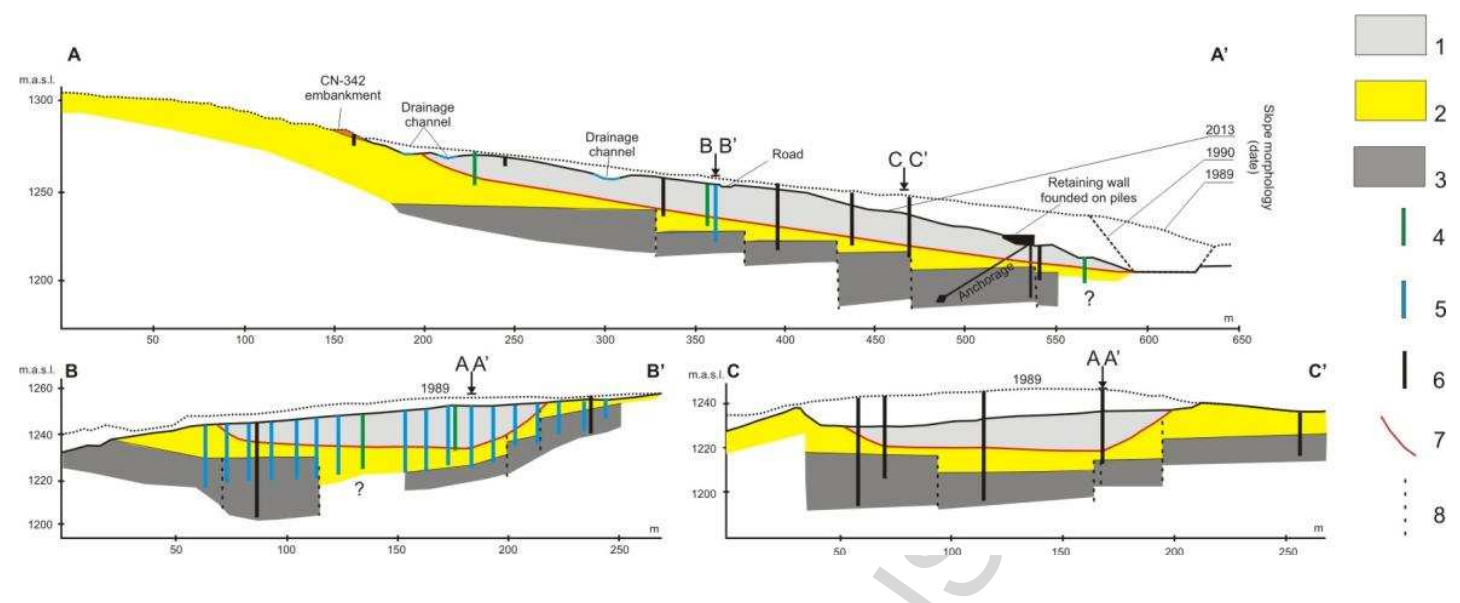

Figure 6 

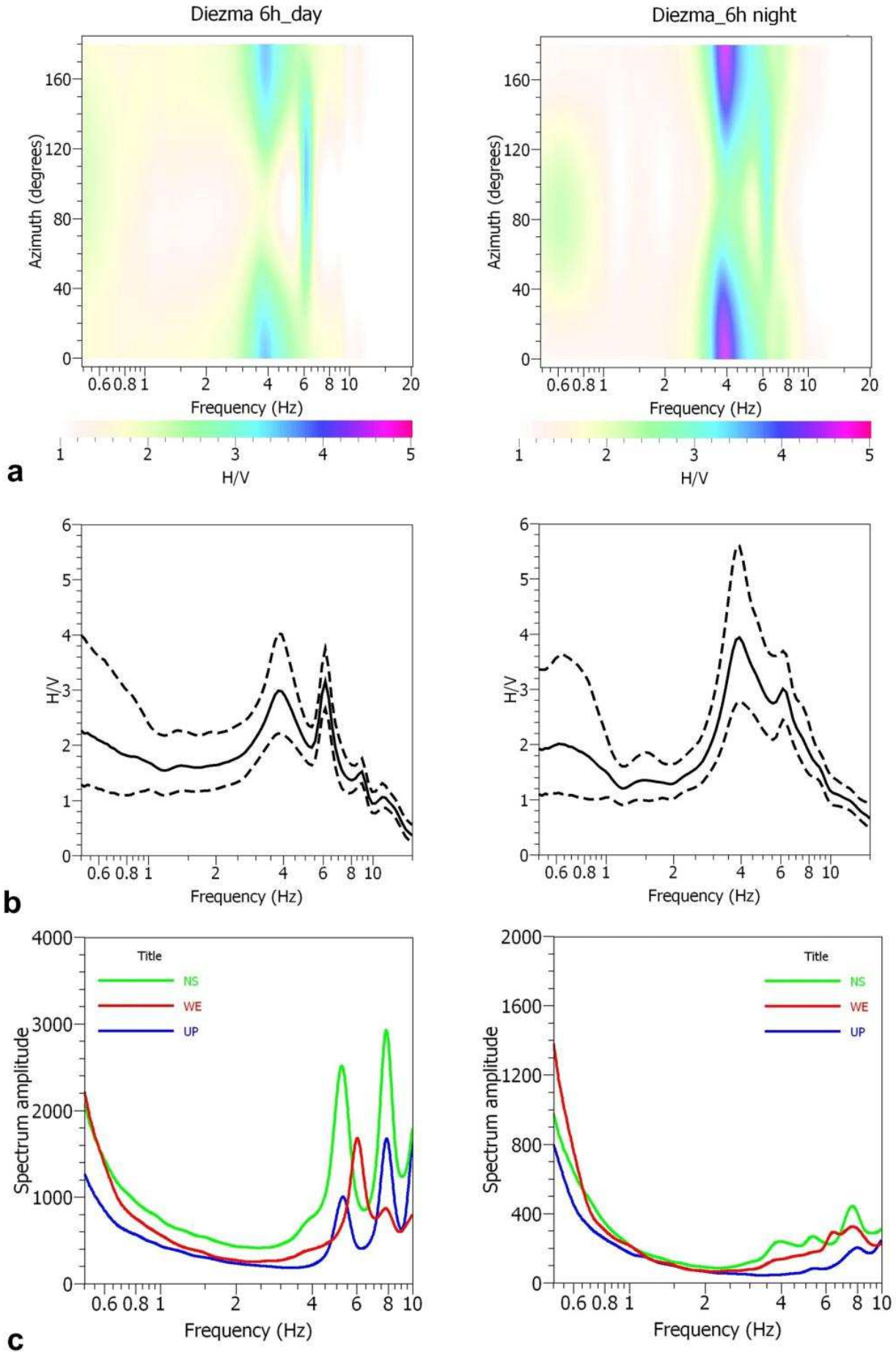

Figure 7 


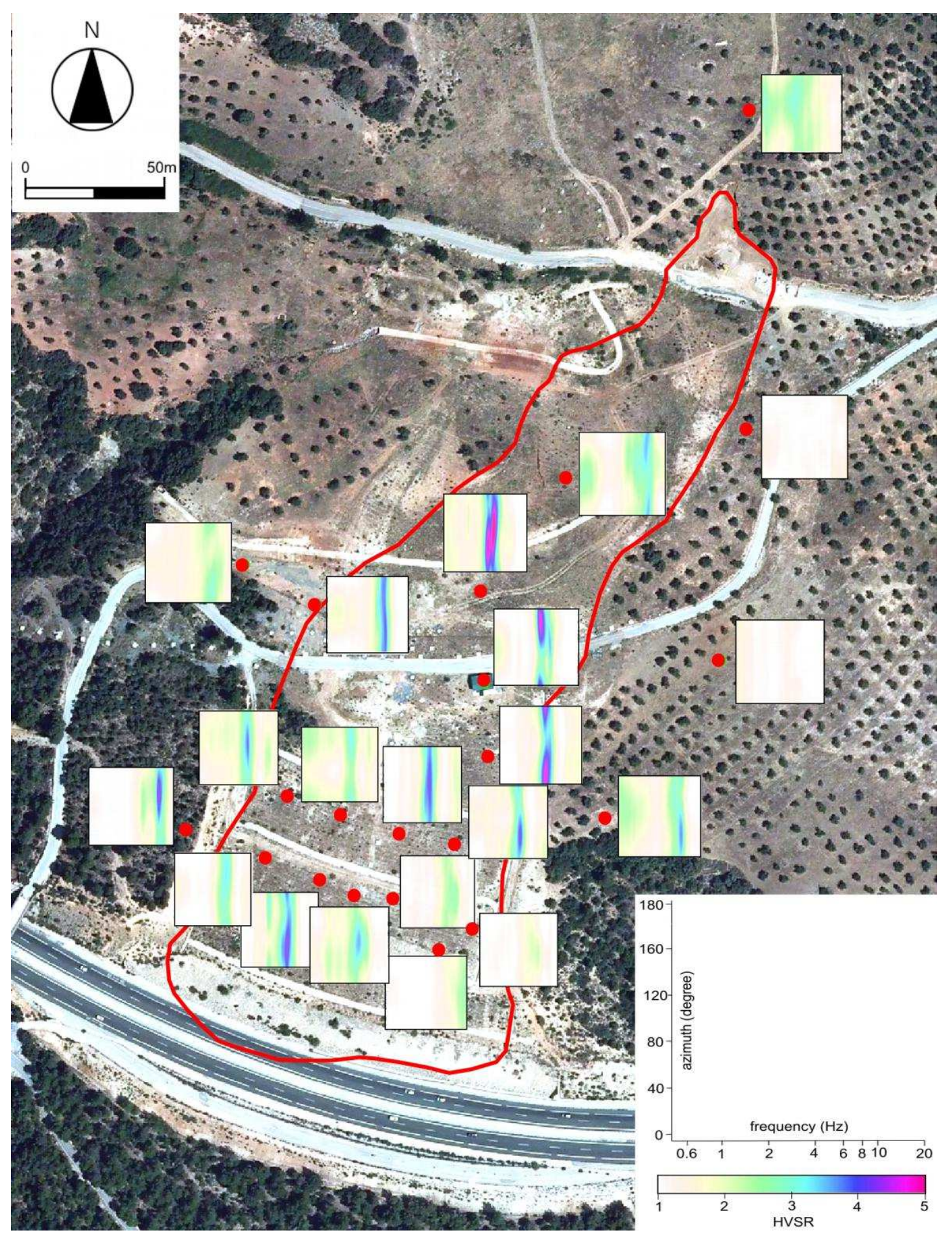

Figure 8 

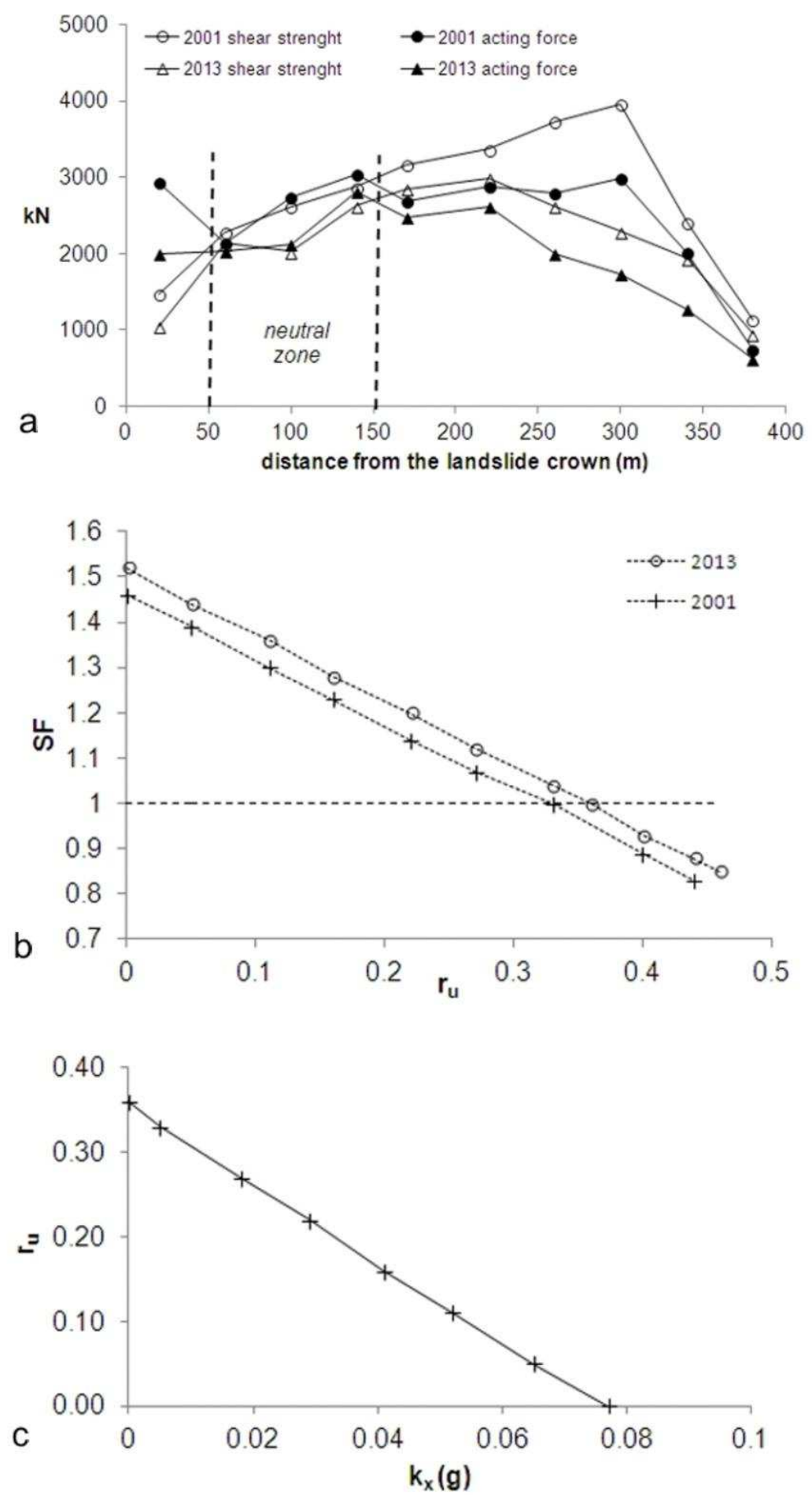

Figure 9 


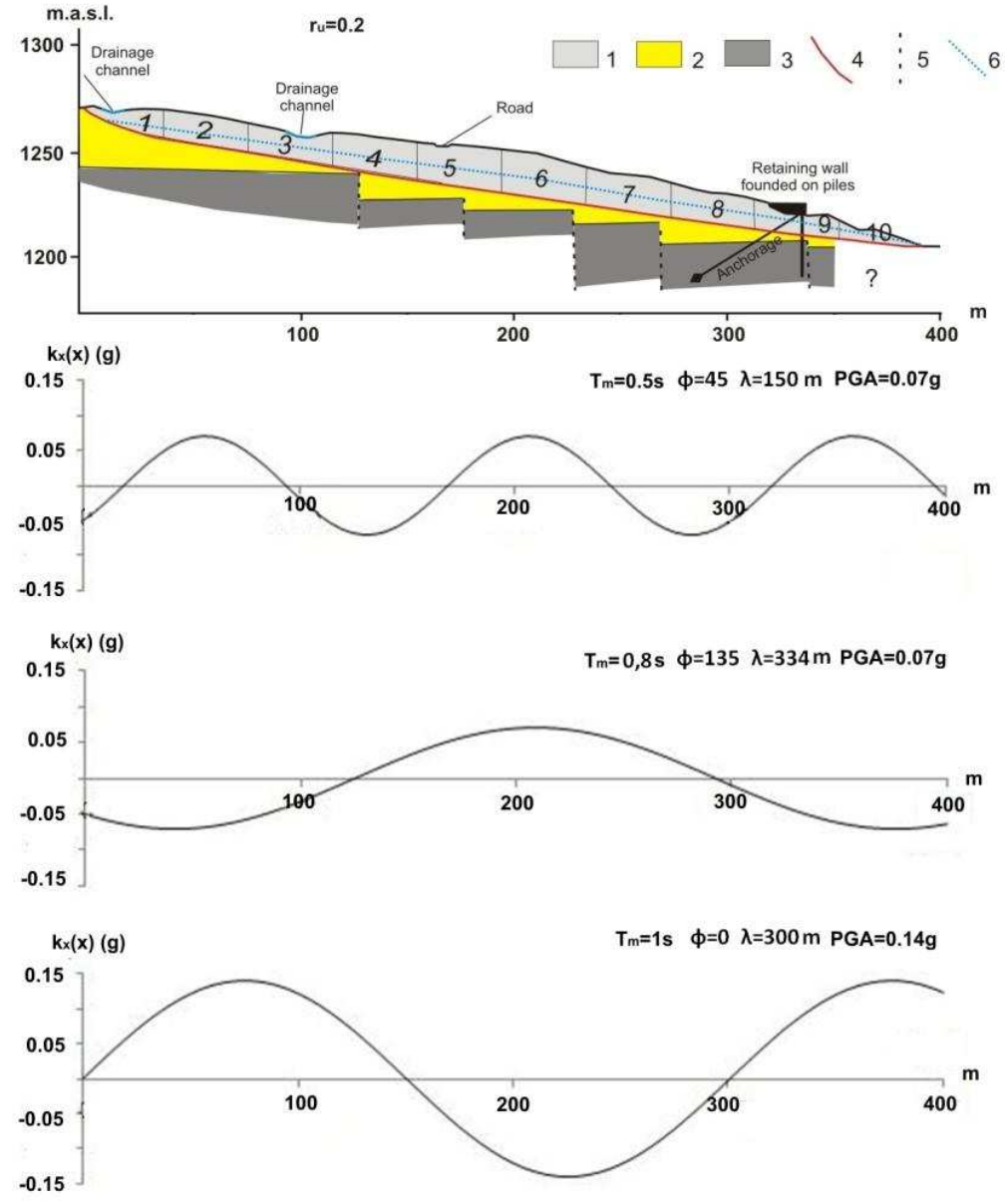

Figure 10 

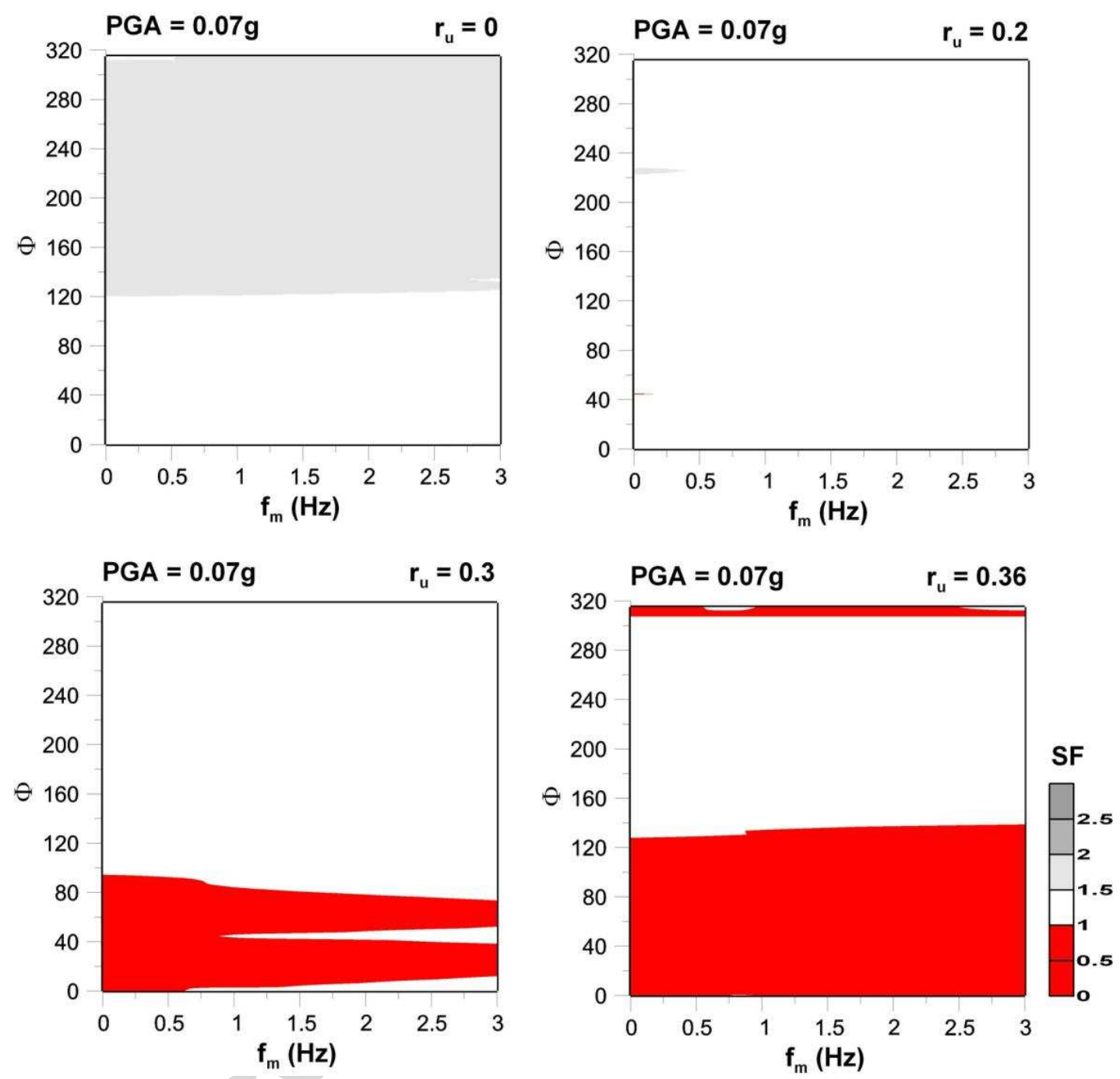

Figure 11 

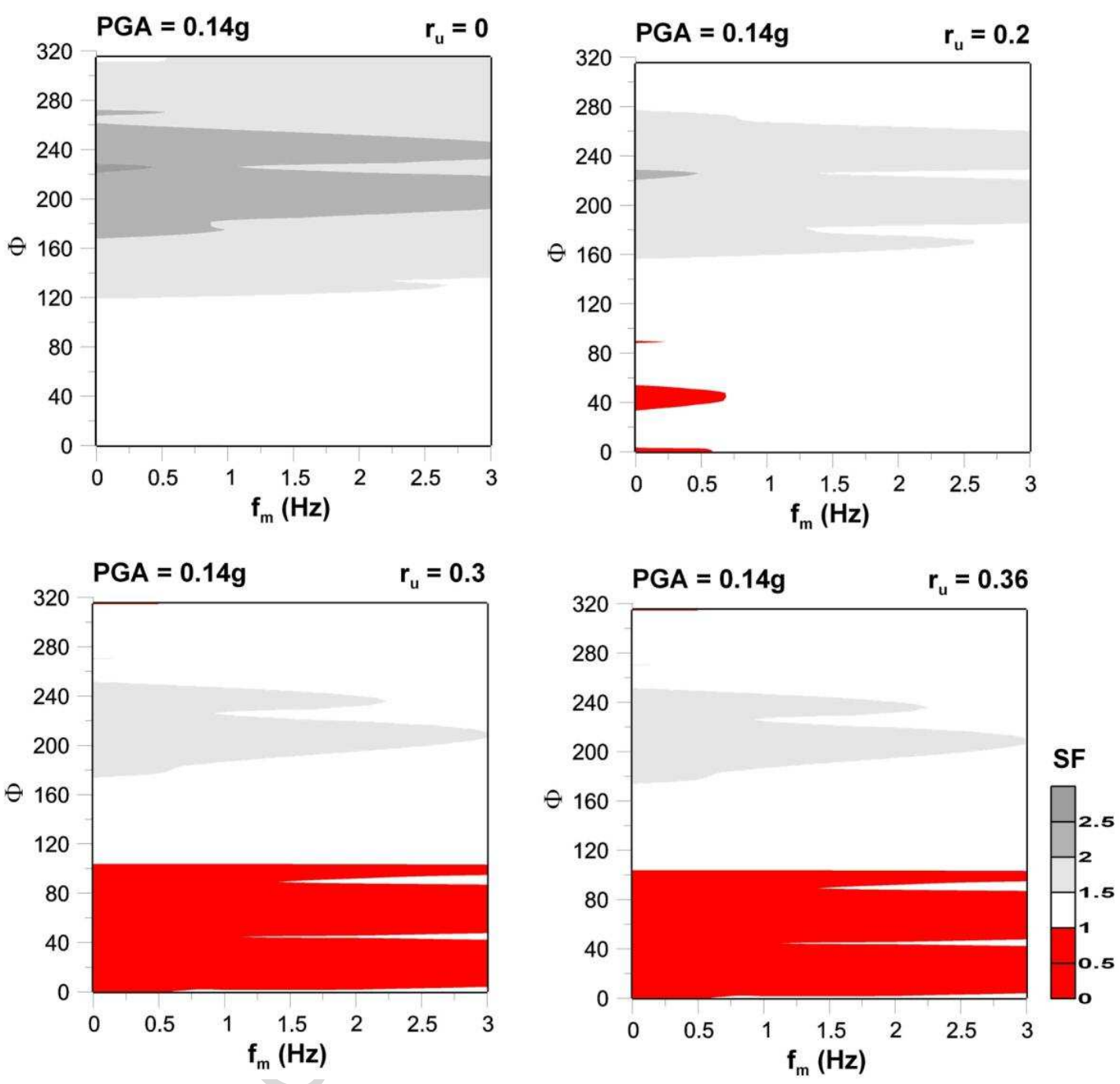

Figure 12 


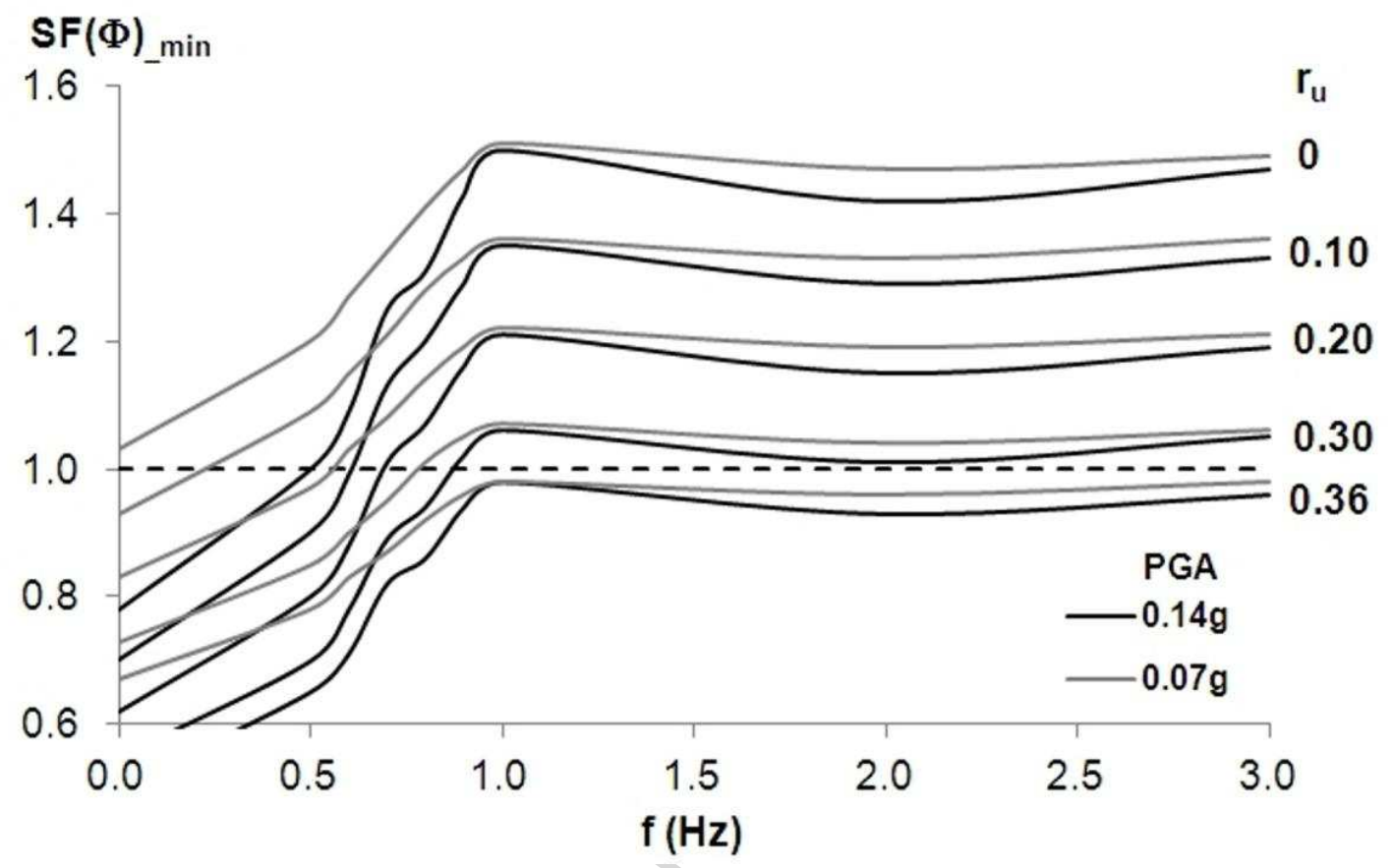

Figure 13 
Table 1

\begin{tabular}{|c|c|c|}
\hline Year & Landslide evidences & Interventions \\
\hline Before 1990 & $\begin{array}{l}\text { Not uniform olive tree cover of the } \\
\text { slope indicating a probable unstable } \\
\text { area. }\end{array}$ & $\begin{array}{l}\text { The CN-342 old road to Granada already } \\
\text { exists. }\end{array}$ \\
\hline $1990-1992$ & $\square \quad$ Two earthslides affected the cut. & $\begin{array}{l}\text { Construction of the A-92 highway. } \\
\text { A } 30 \text { m height man-made trench was } \\
\text { realized at the bottom of the slope (1990). } \\
\quad \text { Two re-shapes of the cut were performed. }\end{array}$ \\
\hline 1991 & $\begin{array}{l}\square \quad \text { A deep landslide in the cut involving } \\
\text { the A-92 highway. }\end{array}$ & $\begin{array}{l}\text { A new re-shape of the slope was } \\
\text { performed. }\end{array}$ \\
\hline 1996 & $\begin{array}{l}\text { Minor landslides occurred from the } \\
\text { trench wall. }\end{array}$ & $\begin{array}{l}\text { An intermediate berm and the re-shape of } \\
\text { the slope was made. }\end{array}$ \\
\hline $1998-1999$ & $\begin{array}{l}\text { Shallow landslides occurred from the } \\
\text { trench wall (1998). } \\
\text { Several longitudinal ground cracks } \\
\text { involved the slope up to about } 400 \mathrm{~m} \\
\text { far from the roadway (1998), most of } \\
\text { them coinciding with the boundaries } \\
\text { of the } 2001 \text { general failure. }\end{array}$ & $\begin{array}{l}\text { Fence at the bottom of the cut was built to } \\
\text { preserve the A-92 highway (1998). } \\
\text { First geological survey. } \\
6 \text { boreholes were drilled (1999). } \\
\text { Not published technical reports by the } \\
\text { "Junta de Andalucía" (1998-1999). }\end{array}$ \\
\hline 2000 & $\begin{array}{l}\text { An earthslide occurred at the bottom } \\
\text { of the slope involving the A92 } \\
\text { highway. }\end{array}$ & $\begin{array}{l}\text { Proposal of a first engineering-geological } \\
\text { model of the landslide slope. } \\
\text { A new re-shape of the slope was } \\
\text { performed. } \\
\text { A retaining rock fill was realized at the } \\
\text { bottom of the slope. }\end{array}$ \\
\hline 2001 & $\begin{array}{l}\square \text { General failure of the Diezma } \\
\text { earthslide on } 18 / 03 / 2001 \text { : total } \\
\text { estimated volume } 1.2 \mathrm{Mm}^{3} \text {. } \\
\text { Several ground cracks up to } 70 \mathrm{~cm} \\
\text { opened and many scarps up to } 4-5 \mathrm{~m} \\
\text { height are distributed along the } \\
\text { slope. } \\
\text { The A-92 highway was interrupted } \\
\text { and closed. } \\
\text { The CN-342 road and the road to } \\
\text { hotel "Señorío de Rías" were heavily } \\
\text { damaged. }\end{array}$ & $\begin{array}{l}\square \text { The landslide debris was removed from } \\
\text { the A-92 highway. } \\
\text { A temporary roadway was constructed to } \\
\text { restore the traffic of the A-92 highway. } \\
\text { The CN-342 road was restored. } \\
\text { The landslide debris was removed on the } \\
\text { slope and the ground cracks were sealed. } \\
4 \text { m deep drainage trenches were } \\
\text { constructed. } \\
\text { A net of drainage ditches was constructed } \\
\text { along the slope. } \\
\text { Four barriers of drainage wells were } \\
\text { realized. } \\
\text { An anchored retaining wall with drainage } \\
\text { trenches and founded by piles, was } \\
\text { constructed at the bottom of the slope. } \\
13 \text { boreholes were drilled. }\end{array}$ \\
\hline $2002-2005$ & $\begin{array}{l}\square \text { Ground cracks opened on the slope, } \\
\text { along the CN-342 and road to hotel. } \\
\text { Some drainage wells deformed and } \\
\text { some ditches cracked. }\end{array}$ & $\begin{array}{l}29 \text { benchmarks for topographic control } \\
\text { were installed as well as } 10 \text { inclinometers } \\
\text { (2002). } \\
9 \text { boreholes were drilled (2005). }\end{array}$ \\
\hline $2006-2009$ & $\begin{array}{l}\text { Ground cracks opened on the slope, } \\
\text { along the CN-342 road and the road } \\
\text { to hotel. }\end{array}$ & $\begin{array}{l}13 \text { new drainage wells (2009). } \\
\square \quad \text { Drainage system for the spring (2009). }\end{array}$ \\
\hline $2010-2012$ & $\begin{array}{l}\square \quad \text { Earthslide re-activation. } \\
\text { The CN-342 road and the road to the } \\
\text { hotel were newly damaged. }\end{array}$ & $\begin{array}{l}\text { Geological survey (Azañón et al., 2010, } \\
\text { Rodríguez-Peces et al., 2011a). } \\
\text { The CN-342 was newly restored, a rock } \\
\text { fill wall was constructed and the cracks } \\
\text { sealed. }\end{array}$ \\
\hline
\end{tabular}




\begin{tabular}{|l|l|ll|}
\hline & & $\square$ & $\begin{array}{l}3 \text { (2010) +3 (2012) boreholes were } \\
\text { drilled. }\end{array}$ \\
\hline 2012-2013 & $\square \begin{array}{l}\text { Ground cracks re-opened on the } \\
\text { slope and along the CN-342 road } \\
\text { and the road to the hotel. }\end{array}$ & $\square \begin{array}{l}\text { Geological survey (this paper). } \\
\text { Geophysical investigations (this paper). }\end{array}$ \\
& $\begin{array}{l}\text { Earthslides developed at the crown } \\
\text { and northeast flank of landslide. }\end{array}$ & $\begin{array}{l}\text { New high resolution engineering- } \\
\text { geological model of the landslide slope } \\
\text { (this paper). }\end{array}$ \\
\hline
\end{tabular}


Table 2

\begin{tabular}{|c|c|c|c|c|c|c|c|c|}
\hline \multirow[b]{2}{*}{ slice } & \multirow{2}{*}{$\begin{aligned} T_{m} & =0.5 \mathrm{~s} \\
\phi & =0\end{aligned}$} & $\begin{array}{l}\lambda=150 \\
\mathrm{~m}\end{array}$ & \multicolumn{4}{|c|}{$\begin{array}{l}P G A=0.07 \mathrm{~g} \\
\quad k x(\mathrm{~g}) \text { for different wave phases }\end{array}$} & \multirow[b]{2}{*}{$\phi=270$} & \multirow[b]{2}{*}{$\phi=315$} \\
\hline & & $\phi=45$ & $\phi=90$ & $\phi=135$ & $\phi=180$ & $\phi=225$ & & \\
\hline 1 & -0.024 & 0.025 & 0.060 & 0.059 & 0.024 & -0.025 & -0.060 & -0.059 \\
\hline 2 & 0.058 & 0.057 & 0.023 & -0.025 & -0.058 & -0.057 & -0.023 & 0.025 \\
\hline 3 & 0.017 & -0.030 & -0.060 & -0.054 & -0.017 & 0.030 & 0.060 & 0.054 \\
\hline 4 & -0.061 & -0.051 & -0.011 & 0.035 & 0.061 & 0.051 & 0.011 & -0.035 \\
\hline 5 & -0.005 & 0.040 & 0.062 & 0.047 & 0.005 & -0.040 & -0.062 & -0.047 \\
\hline 6 & 0.062 & 0.043 & -0.001 & -0.045 & -0.062 & -0.043 & 0.001 & 0.045 \\
\hline 7 & -0.008 & -0.049 & -0.062 & -0.038 & 0.008 & 0.049 & 0.062 & 0.038 \\
\hline 8 & -0.061 & -0.033 & 0.014 & 0.053 & 0.061 & 0.033 & -0.014 & -0.053 \\
\hline 9 & 0.025 & 0.056 & 0.055 & 0.021 & -0.025 & -0.056 & -0.055 & -0.021 \\
\hline 10 & 0.047 & 0.009 & -0.034 & -0.057 & -0.047 & -0.009 & 0.034 & 0.057 \\
\hline$r_{u}$ & SF & SF & SF & SF & SF & SF & SF & SF \\
\hline 0 & 1.48 & 1.47 & 1.48 & 1.52 & 1.55 & 1.57 & 1.55 & 1.51 \\
\hline 0.1 & 1.34 & 1.33 & 1.34 & 1.37 & 1.4 & 1.41 & 1.4 & 1.37 \\
\hline 0.2 & 1.19 & 1.19 & 1.2 & 1.23 & 1.25 & 1.27 & 1.25 & 1.23 \\
\hline 0.3 & 1.05 & 1.04 & 1.05 & 1.08 & 1.11 & 1.12 & 1.1 & 1.08 \\
\hline \multirow{2}{*}{0.36} & 0.97 & 0.96 & 0.97 & 0.99 & 1.02 & 1.03 & 1.01 & 0.99 \\
\hline & $\mathrm{T}_{\mathrm{m}}=0.8 \mathrm{~s}$ & $\begin{array}{l}\lambda=334 \\
m\end{array}$ & \multicolumn{2}{|c|}{$P G A=0.07 g$} & & & \multirow[b]{2}{*}{$\phi=270$} & \multirow[b]{2}{*}{$\phi=315$} \\
\hline slice & $\phi=0$ & $\phi=45$ & $\phi=90$ & $\phi=135$ & $\phi=180$ & $\phi=225$ & & \\
\hline 1 & 0.067 & 0.057 & 0.013 & -0.039 & -0.067 & -0.057 & -0.013 & 0.039 \\
\hline 2 & 0.056 & 0.013 & -0.038 & -0.067 & -0.056 & -0.013 & 0.038 & 0.067 \\
\hline 3 & 0.009 & -0.041 & -0.067 & -0.054 & -0.009 & 0.041 & 0.067 & 0.054 \\
\hline 4 & -0.044 & -0.068 & -0.052 & -0.006 & 0.044 & 0.068 & 0.052 & 0.006 \\
\hline 5 & -0.068 & -0.050 & -0.003 & 0.046 & 0.068 & 0.050 & 0.003 & -0.046 \\
\hline 6 & -0.048 & 0.001 & 0.049 & 0.068 & 0.048 & -0.001 & -0.049 & -0.068 \\
\hline 7 & 0.004 & 0.051 & 0.068 & 0.045 & -0.004 & -0.051 & -0.068 & -0.045 \\
\hline 8 & 0.053 & 0.068 & 0.042 & -0.008 & -0.053 & -0.068 & -0.042 & 0.008 \\
\hline 9 & 0.066 & 0.037 & -0.014 & -0.057 & -0.066 & -0.037 & 0.014 & 0.057 \\
\hline 10 & 0.030 & -0.021 & -0.060 & -0.064 & -0.030 & 0.021 & 0.060 & 0.064 \\
\hline$r_{u}$ & SF & SF & SF & SF & SF & SF & SF & SF \\
\hline 0.0 & 1.5 & 1.5 & 1.5 & 1.5 & 1.5 & 1.5 & 1.5 & 1.5 \\
\hline 0.1 & 1.4 & 1.4 & 1.4 & 1.4 & 1.4 & 1.4 & 1.4 & 1.4 \\
\hline 0.2 & 1.2 & 1.2 & 1.2 & 1.2 & 1.2 & 1.2 & 1.2 & 1.2 \\
\hline 0.3 & 1.1 & 1.1 & 1.1 & 1.1 & 1.1 & 1.1 & 1.1 & 1.1 \\
\hline \multirow[t]{2}{*}{0.4} & 1.0 & 1.0 & 1.0 & 1.0 & 1.0 & 1.0 & 1.0 & 1.0 \\
\hline & $\mathrm{T}_{\mathrm{m}}=1.0 \mathrm{~s}$ & $\begin{array}{l}\lambda=300 \\
\mathrm{~m}\end{array}$ & \multicolumn{2}{|c|}{$\begin{array}{r}P G A=0.14 \mathrm{~g} \\
k x(g) \text { fo }\end{array}$} & th wave & ases & & \\
\hline slice & $\phi=0$ & $\phi=45$ & $\phi=90$ & $\phi=135$ & $\phi=180$ & $\phi=225$ & $\phi=270$ & $\phi=315$ \\
\hline 1 & 0.135 & 0.113 & 0.026 & -0.077 & -0.135 & -0.113 & -0.026 & 0.077 \\
\hline 2 & 0.113 & 0.026 & -0.076 & -0.134 & -0.113 & -0.026 & 0.076 & 0.134 \\
\hline 3 & 0.019 & -0.082 & -0.135 & -0.109 & -0.019 & 0.082 & 0.135 & 0.109 \\
\hline
\end{tabular}




\begin{tabular}{|ccccccccc|}
4 & -0.087 & -0.135 & -0.104 & -0.012 & 0.087 & 0.135 & 0.104 & 0.012 \\
5 & -0.136 & -0.100 & -0.005 & 0.092 & 0.136 & 0.100 & 0.005 & -0.092 \\
6 & -0.095 & 0.001 & 0.097 & 0.136 & 0.095 & -0.001 & -0.097 & -0.136 \\
7 & 0.008 & 0.102 & 0.136 & 0.090 & -0.008 & -0.102 & -0.136 & -0.090 \\
8 & 0.106 & 0.135 & 0.085 & -0.015 & -0.106 & -0.135 & -0.085 & 0.015 \\
9 & 0.132 & 0.073 & -0.029 & -0.113 & -0.132 & -0.073 & 0.029 & 0.113 \\
10 & 0.061 & -0.042 & -0.119 & -0.127 & -0.061 & 0.042 & 0.119 & 0.127 \\
& & & & & & & & \\
& & & & & & & & \\
$\mathrm{r}_{\mathrm{u}}$ & $\mathrm{SF}$ & $\mathrm{SF}$ & $\mathrm{SF}$ & $\mathrm{SF}$ & $\mathrm{SF}$ & $\mathrm{SF}$ & $\mathrm{SF}$ & $\mathrm{SF}$ \\
0 & 1.5 & 1.5 & 1.5 & 1.5 & 1.5 & 1.5 & 1.5 & 1.5 \\
0.1 & 1.4 & 1.4 & 1.4 & 1.4 & 1.4 & 1.4 & 1.4 & 1.4 \\
0.2 & 1.2 & 1.2 & 1.2 & 1.2 & 1.2 & 1.2 & 1.2 & 1.2 \\
0.3 & 1.1 & 1.1 & 1.1 & 1.1 & 1.1 & 1.1 & 1.1 & 1.1 \\
0.36 & 1.0 & 1.0 & 1.0 & 1.0 & 1.0 & 1.0 & 1.0 & 1.0 \\
\hline
\end{tabular}


Table 3

\begin{tabular}{|c|c|c|c|c|c|c|}
\hline$\lambda$ & $\mathrm{m}$ & 100 & 150 & 300 & 350 & 400 \\
\hline $\mathrm{f}$ & $\mathrm{Hz}$ & 3.00 & 2.00 & 1.00 & 0.85 & 0.75 \\
\hline $\mathrm{T}_{\mathrm{m}}$ & $\mathrm{s}$ & 0.33 & 0.50 & 1.00 & 1.18 & 1.33 \\
\hline $\mathrm{T}_{\mathrm{l}} / \mathrm{T}_{\mathrm{m}}$ & & 4.03 & 2.66 & 1.33 & 1.13 & 1.00 \\
\hline $\mathrm{T}_{\mathrm{s}} / \mathrm{T}_{\mathrm{m}}$ & & 0.61 & 0.40 & 0.20 & 0.17 & 0.15 \\
\hline x_disp (Al 1.00m/s) & $\mathrm{m}$ & 0.31 & 0.95 & 1.70 & 1.50 & 1.45 \\
\hline x_disp (Al 0.10m/s) & $\mathrm{m}$ & 0.09 & 0.18 & 0.45 & 0.24 & 0.23 \\
\hline x_disp (Al 0.01m/s) & $\mathrm{m}$ & 0.02 & 0.02 & 0.01 & 0.02 & 0.01 \\
\hline
\end{tabular}




\section{Highlights}

- unconventional pseudostatic analysis experienced for the Diezma landslide (Spain)

- engineering-geological model and geophysical measurement supported the analysis

- results demonstrate sensitivity of the safety factor to frequency, phases and PGA

- earthquake-induced displacements evaluated considering 1D and 2D seismic effects 